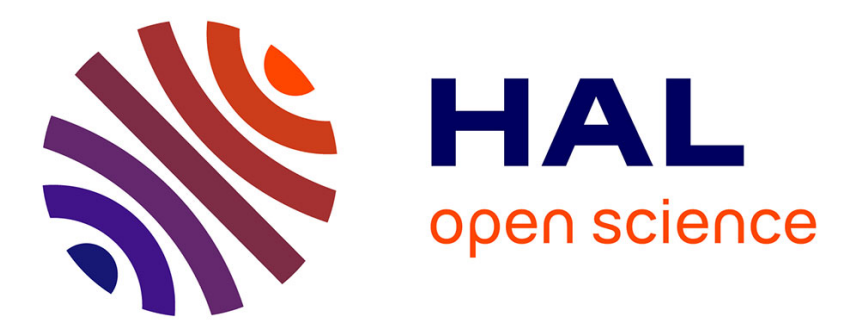

\title{
Development of the Gulf of Guayaquil (Ecuador) during the Quaternary as an effect of the North Andean block tectonic escape
}

C. Witt, Jacques Bourgois, F. Michaud, M. Ordonez, N. Jimenez, M. Sosson

\section{- To cite this version:}

C. Witt, Jacques Bourgois, F. Michaud, M. Ordonez, N. Jimenez, et al.. Development of the Gulf of Guayaquil (Ecuador) during the Quaternary as an effect of the North Andean block tectonic escape. Tectonics, 2006, 25 (3), 22 pp. 10.1029/2004TC001723 . hal-00407626

\section{HAL Id: hal-00407626 \\ https://hal.science/hal-00407626}

Submitted on 29 May 2021

HAL is a multi-disciplinary open access archive for the deposit and dissemination of scientific research documents, whether they are published or not. The documents may come from teaching and research institutions in France or abroad, or from public or private research centers.
L'archive ouverte pluridisciplinaire HAL, est destinée au dépôt et à la diffusion de documents scientifiques de niveau recherche, publiés ou non, émanant des établissements d'enseignement et de recherche français ou étrangers, des laboratoires publics ou privés.

$$
\text { Copyright }
$$




\title{
Development of the Gulf of Guayaquil (Ecuador) during the Quaternary as an effect of the North Andean block tectonic escape
}

\author{
César Witt, ${ }^{1,2}$ Jacques Bourgois, ${ }^{1,2,3,4}$ François Michaud, ${ }^{1,2}$ Martha Ordoñez, ${ }^{5}$ \\ Nelson Jiménez, ${ }^{5}$ and Marc Sosson ${ }^{1}$ \\ Received 5 August 2004; revised 27 December 2005; accepted 17 March 2006; published 21 June 2006.
}

[1] Interpretation of industrial multichannel seismic profiles and well data are used to identify the main tectonic features of the Gulf of Guayaquil (GG) area. These include two E-W trending major detachments: the Posorja and the Jambelí detachment systems, which represent half grabens with oppositely dipping detachments, to the south and to the north, respectively. The NE-SW trending Puná-Santa Clara fault system developed as a transfer fault system between the Posorja and the Jambelí detachments. The Esperanza and the Jambelí basins exhibit 3-4 $\mathrm{km}$ of sediment that accumulated during the past 1.61.8 Myr. The Puná-Santa Clara fault system bounds the Esperanza and the Jambelí basins, evidencing that the evolution of these basins is tightly controlled by the two detachments at depth. To the west, the N-S trending Domito fault system bounding the Posorja detachment system and the Esperanza basin to the west acted as a transfer zone between the shelf area and the continental slope. The Pliocene series show no significant variations in thickness throughout the Gulf of Guayaquil area suggesting that no important tectonic deformation occurred from 5.2 to $1.8-$ 1.6 Ma. The major period of tectonic deformation in the Gulf of Guayaquil area occurred during the Pleistocene times. Three main tectonic steps are identified. From early Pleistocene to $\sim 180 \mathrm{ka}$, major subsidence occurred along the Esperanza and Jambelí basins. From $\sim 180$ to $\sim 140 \mathrm{ka}$, most of the Gulf of Guayaquil area was above sea level during the isotope substage 6 low stand. From $\sim 140$ ka to Present, tectonic activity is restricted along the normal faults bounding the Esperanza basin, the Tenguel fault, and the Puná-Santa Clara and Domito fault systems. A N-S trending tensional stress regime characterizes the

\footnotetext{
${ }^{1}$ UMR Geosciences Azur, Observatoire Océanologique de Villefranchesur-Mer, Nice, France.

${ }^{2}$ Escuela Politécnica Nacional, Departamento de Geología, Quito, Ecuador.

${ }^{3}$ Centre National de la Recherche Scientifique, Paris, France.

${ }^{4}$ Institut de Recherche pour le Développement, Paris, France.

${ }^{5}$ Geological Research Centre of Guayaquil, Petroproducción, Guayaquil, Ecuador
}

Copyright 2006 by the American Geophysical Union. 0278-7407/06/2004TC001723
Pleistocene times throughout. The northward drifting of the North Andean block is proposed to control the tectonic evolution and associated subsidence of the Gulf of Guayaquil area. It is also accepted that the collision of the Carnegie ridge with the trench axis has to play a major role in controlling the North Andean block northward drift. Because the Carnegie ridge subduction is possibly an ongoing process, which began prior to the Pliocene, we postulate the alongstrike morphology of the ridge at the origin of interplate coupling variations. The subduction of an along-strike positive relief of the ridge is proposed at the origin of the major tectonic reorganization of the GG area occurring at $\sim 1.8-1.6 \mathrm{Ma}$. Citation: Witt, C., J. Bourgois, F. Michaud, M. Ordoñez, N. Jiménez, and M. Sosson (2006), Development of the Gulf of Guayaquil (Ecuador) during the Quaternary as an effect of the North Andean block tectonic escape, Tectonics, 25, TC3017, doi:10.1029/2004TC001723.

\section{Introduction}

[2] Active tectonic deformation in the Ecuadorian Andes has been the subject of many studies during the last 15 years [Winter and Lavenu, 1989; Soulas et al., 1991; Tibaldi and Ferrari, 1992; Winter et al., 1993; Ego et al., 1996]. Nevertheless, few studies deal with the analyses of the coastal active tectonics and the evolution of the Gulf of Guayaquil $(\mathrm{GG})$ area through time. In the $\mathrm{GG}$ area (Figure 1), the so-called Dolores-Guayaquil Fault System (DGFS) was considered to be part of the eastern active boundary of the North Andean block (NAB), the northward motion of which was proposed to be at the origin of the GG area subsidence [Campbell, 1974; Shepherd and Moberly, 1981]. Deniaud et al. [1999] interpreted the tectonic deformation of the GG area as a consequence of an extensional strain associated with the northward drifting of the NAB. They proposed that the first phase of subsidence took place in the GG area during the Pliocene, the GG area developing as a pull-apart basin along the NAB eastern limit. However, the evolution of the GG area and the role of the NAB eastern limit in its development remain poorly understood.

[3] On the basis of multichannel seismic reflection profiles and well data acquired by Petroecuador (Ecuadorian Petroleum Company) during the past two decades, we document the geodynamic evolution of the GG area for the past 2 Myr. The study area includes (Figure 1b) offshore zones located on either side of the Puná and Santa Clara 

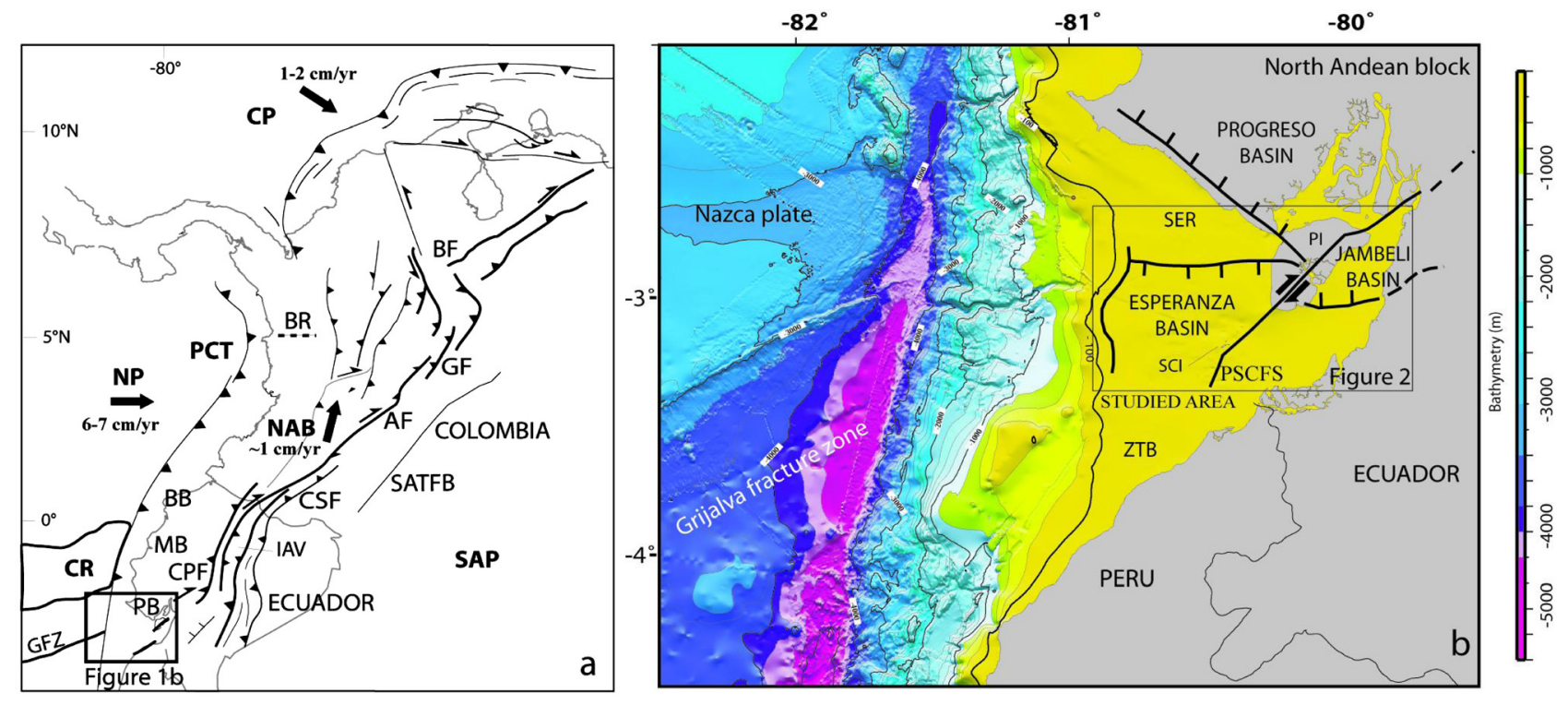

Figure 1. (a) Structural framework of the Andean segment extending from northern Peru to Venezuela showing the NAB limits and the forearc basins of the Ecuadorian segment, modified from Taboada et al. [2000]. (b) Structural sketch of the Gulf of Guayaquil area. Bathymetry of the continental margin and trench is a compilation of data from the Seaperc cruise (J. Bourgois chief scientist) of the R/V Jean Charcot and the Andinaut cruise (J. Bourgois chief scientist) of the R/V L'Atalante. Legend is for both Figures 1a and 1b. AF, Algeciras fault; BB, Borbón basin; BF, Boconó fault; BR, Baudo range; $\mathrm{CP}$, Caribbean plate; CPF, Calacalí-Pallatanga fault; CR, Carnegie ridge; CSF, Chingual-La Sofia fault; GF, Guaicaramo fault; GFZ, Grijalva fracture zone; IAV, Inter-Andean valley; MB, Manabí basin; NAB, North Andean block; NP, Nazca plate; PB, Progreso basin; PCT, Peru-Chile trench; PI, Puná island; PSCFS, Puná-Santa Clara fault system; SAFTB, Sub Andean fault and thrust belt; SAP, South America plate; SCI, Santa Clara island; SER, Santa Elena rise; ZTB, Zorritos-Tumbes basin.

islands. Data are confined to above $100 \mathrm{~m}$ water depth, landward from the shelf slope break. We have identified three major tectonic features: the Esperanza and Jambelí basins and a diapiric zone located at the seaward edge of the continental platform. The evolution of these features is controlled by six main active fault systems (Figure 2), which include: the Puná-Santa Clara fault system (PSCFS), the Posorja detachment system (PDS), the Tenguel fault, the Domito fault system (DFS), the Esperanza graben, and the Jambelí detachment system (JDS). These major structures have been poorly characterized in previous studies. Their description improves available constraints on the tectonic reconstruction and subsidence history of the area. In addition, we present detailed mapping of the active structures and their evolution through time, and a geodynamic scenario for the Pliocene and Quaternary based on these constraints.

\section{Geodynamics and Geologic Framework}

[4] The Nazca plate (Figure 1) is subducting eastward beneath the South America plate at a rate of about $6-7 \mathrm{~cm} / \mathrm{yr}$ in an E-W direction [Freymueller et al., 1993; Kellogg and Vega, 1995; Trenkamp et al., 2002]. The dip angle of subduction ranges between $25^{\circ}$ and $35^{\circ}$ [Pennington, 1981; Guillier et al., 2001]. The Carnegie ridge is an approximately E-W trending bathymetric high of the Nazca plate entering the subduction between $1^{\circ} \mathrm{N}$ and $2^{\circ} \mathrm{S}$ latitude. Along the collision area of the Carnegie ridge with the trench, the Ecuadorian continental margin is being uplifted at Present [Lonsdale, 1978]. Daly [1989], Benitez [1995], Aalto and Miller [1999], Pedoja [2003], and Cantalamessa and Di Celma [2004] have proposed that the evolution of the forearc basins such as Borbón and Manabí basins were controlled by the Carnegie ridge subduction. Also the chemistry of the active volcanic arc [Bourdon et al., 2003; Samaniego et al., 2005] and cooling uplift-related Andean rates [Steinmann et al., 1999; Spikings et al., 2001] were related with the timing of arrival of the Carnegie ridge to the trench axis. The proposed ages for the ridge-trench collision lie in the range between 1 and $15 \mathrm{Ma}$ (i.e., Lonsdale [1978] and Spikings et al. [2001], respectively, other ages lying in this range were also proposed by Rea and Malfait [1974], Hey [1977], Lonsdale and Klitgord [1978], and Wilson and Hey [1995]). A flat slab coincident with the zone of Carnegie ridge subduction was proposed from seismological global data [Gutscher et al., 1999]. This flat slab configuration was first constrained by two events located at $250-300 \mathrm{~km}$ from the trench and then related to a model of adakitic volcanism generation [Gutscher et al., 1999; Bourdon et al., 2003]. Seismological studies using a dense network of 54 stations installed in northern Ecuador 


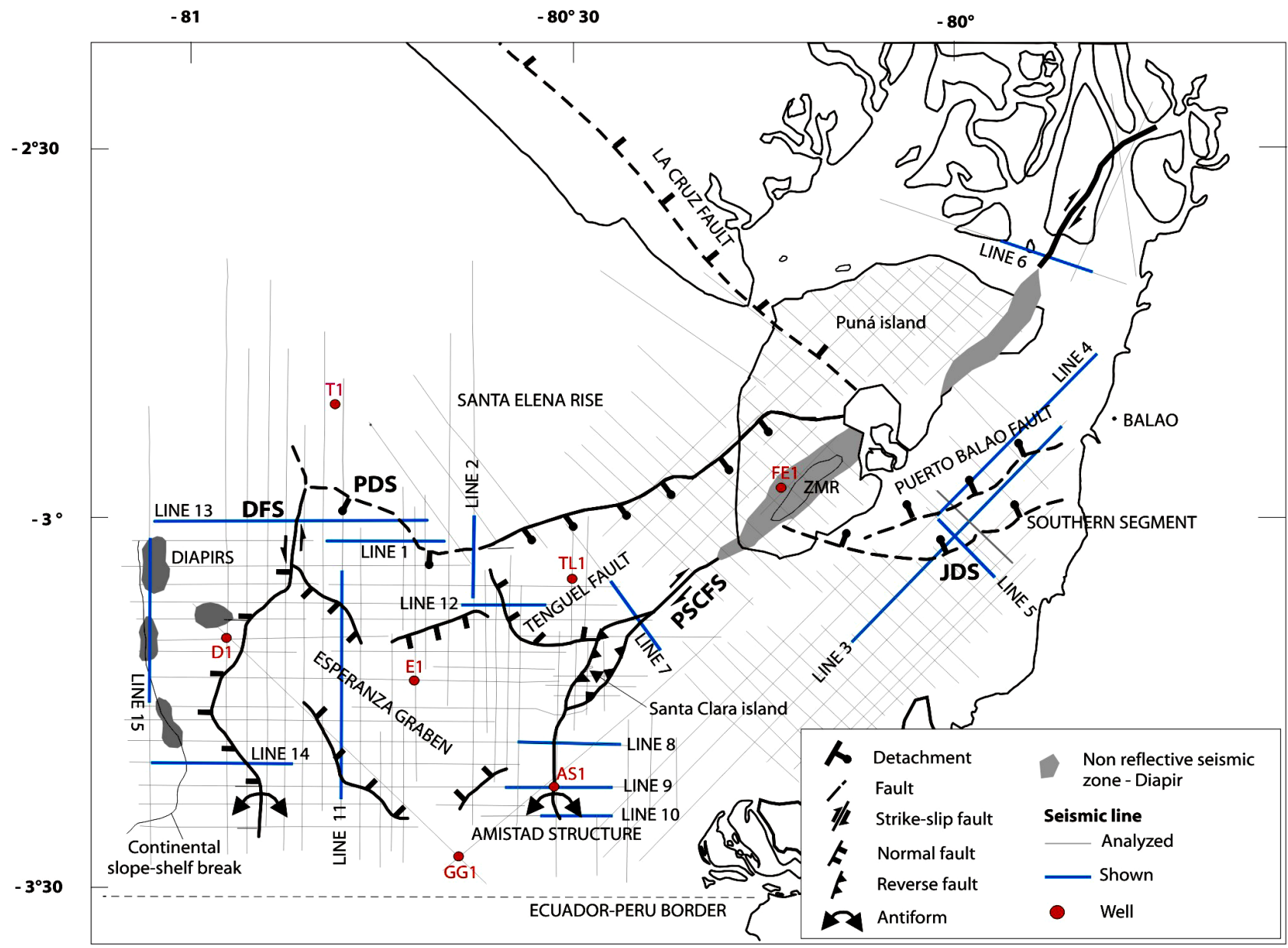

Figure 2. Structural map of the GG area. Solid line shows the active tectonic features. Dashed line shows the tectonic features with no clear activity today. The nonreflective seismic zones and diapirs are mapped down to $2 \mathrm{~s}$ TWTT. AS1, Amistad Sur 1 well; DFS, Domito fault system; D1, Domito 1 well; E1, Esperanza 1 well; FE1, Fe1 well; GG1, Golfo de Guayaquil 1 well; JDS, Jambelí detachment system; PDS, Posorja detachment system; PSCFS, Puná-Santa Clara fault system; T1, Tiburon 1 well; TL1, Tenguel 1 well; ZMR, Zambapala mountain range.

[Guillier et al., 2001] do not reveal any major changes in the slab dip angle at depth associated with the Carnegie ridge.

[5] At $\sim 1^{\circ} \mathrm{N}$ latitude, the trench axis exhibits a change in trend from N-S to the south to NNE to the north. North of $1^{\circ} \mathrm{N}$, the convergence between the Nazca and South America plates is oblique and produces motion partitioning $[$ Ego et al., 1996]. The North Andean block (NAB) is migrating to the NE along a major right-lateral strike-slip system at a rate of $6 \pm 2 \mathrm{~mm} / \mathrm{yr}$ [Trenkamp et al., 2002]. The oblique convergence and the subduction of the Carnegie ridge have been proposed to be at the origin of the northward drifting of the NAB [Pennington, 1981; Ego et al., 1996]. Along the Ecuadorian coast the NAB exhibits mainly oceanic terrane accreted to the Andean continental margin. The obduction of these oceanic terranes occurred between the Late Cretaceous and the late Eocene [i.e., Feininger and Bristow, 1980; Bourgois et al., 1982, 1987, 1990; Benitez et al., 1993; Jaillard et al., 1997; Reynaud et al., 1999; Lapierre et al., 2000; Mamberti et al., 2003]. Even so, faults limiting continental crust tectonic units also accommodate NAB motion. Winter and Lavenu [1989], Soulas et al. [1991], and Ego et al. [1996] described the NAB eastern limits as a major system of dextral faults cutting across the Ecuadorian Andes through several active fault segments (Figure 1a) such as the Calacalí-Pallatanga fault, the thrust faults along the Inter-Andean valley, and the Chingual-La Sofia fault. Along the Inter-Andean valley this system would form a restraining bend along central and northern Ecuadorian Andes [Ego et al., 1996; Winkler et al., 2005]. In Colombia, the fault and thrust belt of the eastern front of the Oriental Cordillera (i.e., the Algeciras and Guaicaramo faults and the Pamplona indenter) connect to the north with the Boconó fault system in Venezuela. All these structures show features suggesting active deformation [Boinet et al., 1985; Bourgois et al., 1987, 1990; Audemard, 1997; Taboada et al., 2000; Dimate et al., 2003; Velandia et al., 2005; Dhont et al., 2005]. These fault systems show evidence of reactivation or tectonic inversion of older tectonic features and suture zones 


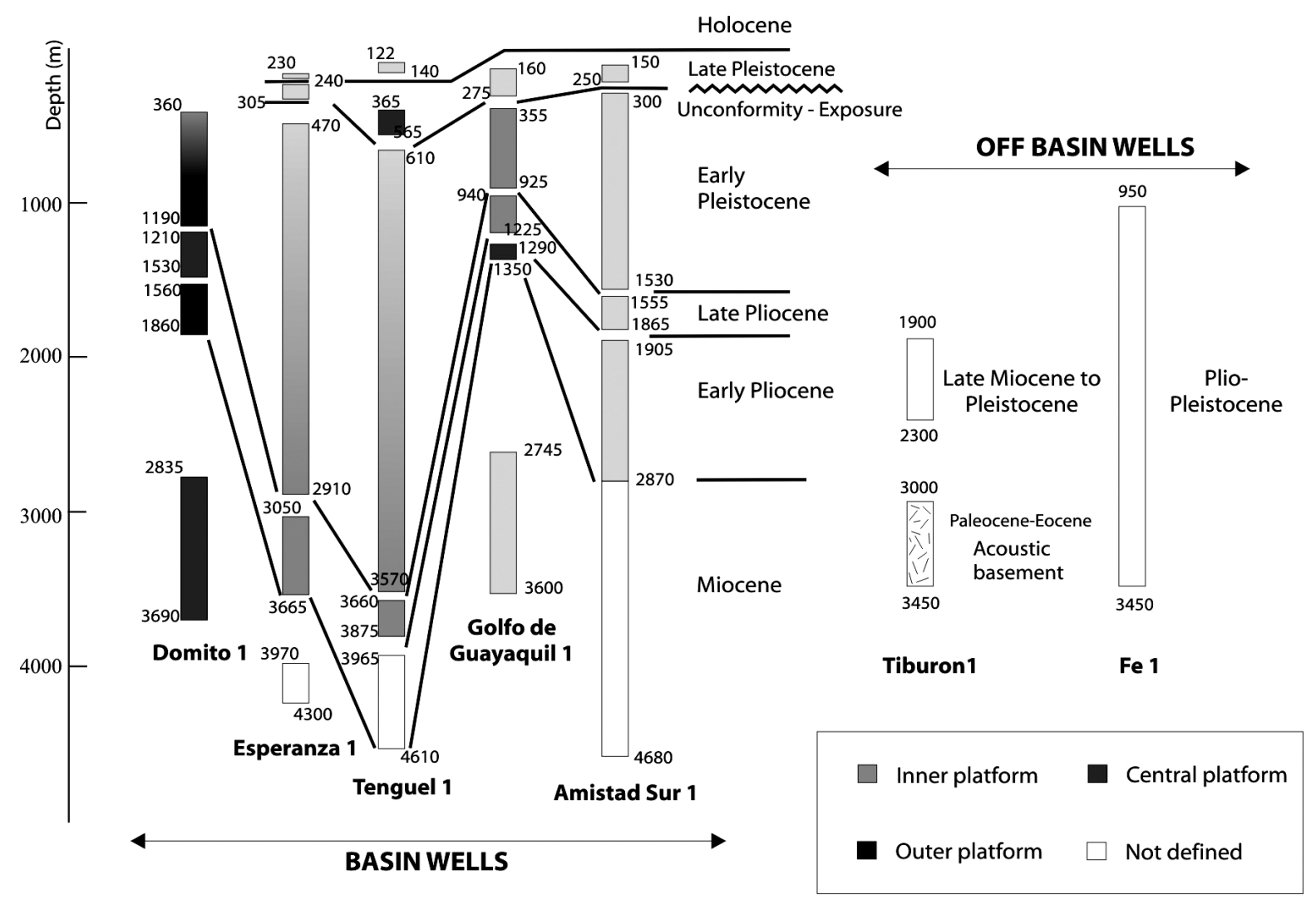

Figure 3. Stratigraphic columns from industrial wells drilled in the GG area. Age distribution is from micropaleontological and pollen assemblages. No well reached oceanic or continental basement. Tiburon 1 well is placed along the Santa Elena rise, away from the basin depocenters. The Tiburon 1 well data are used for basin basement correlations (acoustic basement along lines). See Figure 2 for well location. Numbers refer to depth below seafloor.

[Audemard, 1997; Guillier et al., 2001; Dimate et al., 2003; Winkler et al., 2005]. Even so, other models suggest that the NAB does not act as a single block moving northward and that the accommodation of the deformation is more complicated since the Caribbean plate (Figure 1a) influences the area north of $4-5^{\circ} \mathrm{N}$ [Ego et al., 1996; Taboada et al., 2000; Corredor, 2003; Acosta et al., 2004; Cortés et al., 2005]. This model suggests that the zone of transition between the NE-ENE Nazca plate-related compression to the ESE Caribbean plate-related compression is placed at $4-5^{\circ} \mathrm{N}$ along an E-W trending transfer zone (i.e., the Baudo range, Figure 1a [Taboada et al., 2000]).

[6] The forearc evolution is marked by the development of four main basins, from north to south these include: the Borbón, the Manabí, the Progreso, and the GG (Esperanza and Jambelí) basins. All of these basins show periods of shallowing or deepening of facies as they evolved through time [Benitez, 1995; Deniaud, 2000]. Except in the GG area, the subsidence of the other basins began approximately during the early Miocene. The sediment accumulation of the Esperanza and Jambelí basins is mainly composed of clastic deposits ranging in age from Mio-Pliocene (prerift sequences) to Pleistocene (synrift sequences). The Santa Elena rise separates the Miocene Progreso basin from the Pleistocene GG basins (Figures $1 \mathrm{a}$ and 2). The sediment accumulation of the GG area has recorded the tectonic and climatic signals of the adjacent continental areas. It includes the major continental crustal thinning of the GG area basement and the sediment coastal drainage and transport to the trench. Therefore the GG area is a key zone to develop analyses for constraining the tectonic evolution of the southern boundary of the NAB. Seaward of the GG area, the upper and middle continental slope are characterized by intense deformation along seaward dipping normal faults which constraint a subductionerosion tectonic regime working at depth. At the toe of the continental slope, trench fill sediments are offscraped to form an incipient frontal accretionary prism [Collot et al., 2002; Calahorrano, 2005].

\section{Data}

[7] This study considers the stratigraphy of seven industrial wells located at key sites (Figures 2 and 3). The data include determinations of microfossil and pollen associations as well as the environmental signature of sediment and rock petrology analyses. The selected wells such as Tenguel 
1 and Esperanza 1 are located at sites where high subsidence rate is recorded. The Amistad Sur 1, Fe1, and Domito 1 wells on one side, and the Golfo de Guayaquil 1 and Tiburon 1 wells on the other side were selected because they are located above structural high and along transition zones, respectively. Only the Tiburon 1 well is used for acoustic basement correlations. This well is located away from zones of thick sediment filling, so we did not use it to correlate ages in those zones. The Fel well, which is located over a zone showing no clear seismic reflection resolution, also exhibits poorly defined stratigraphic data. As a consequence, no correlation of the Fel well data with records from the GG area is possible.

[8] The sediment accumulation of the Esperanza and Jambelí basins is mainly composed of clastic deposits ranging in age from Mio-Pliocene (prerift sequences) to Pleistocene (synrift sequences). The early middle Miocene sequences (Subibaja Formation) accumulate in an outer platform to continental environment. The middle to late Miocene transitional sequences (Progreso Formation) and the Pliocene-Pleistocene marine sequences (Lower and Upper Puná formations) were deposited in an inner platform environment [Benitez, 1995, and references therein]. Deniaud et al. [1999] identified at least four subsidence phases for the GG area: (1) a phase of low subsidence-low sedimentation rates during Mio-Pliocene, (2) a phase of high subsidence-high sediment deposition rates during early Pleistocene, (3) a phase of low subsidence-low sediment accumulation rates in the late Pleistocene, and (4) a phase of relatively high subsidence-high sediment accumulation rates during the Holocene. No evidence of stratigraphic age exists for phases 3 and 4. In this work, we assume that the GG area evolved through two main steps. The first one, during the Mio-Pliocene is characterized by low subsidence-low sedimentation rates, and the second one, during the Pleistocene, exhibits high subsidence and sedimentation rates that a short exposure phase of the GG area interrupted.

[9] The seismic lines used in this work were collected and processed by different companies between 1980 and 1983. We have analyzed about 100 of them for a total of $\sim 4000 \mathrm{~km}$ (Figure 2). Only $15 \mathrm{key}$ lines are presented in this work. All profiles have been treated using a conventional processing sequence including deconvolution and migration. The analyzed seismic lines show high-quality seismic reflections down to 4-5 s two-way traveltime (TWTT). The poor quality of seismic reflections does not offer proper constraints on the tectonic history of the deeper series.

\section{Interpretation}

[10] The GG area (Figure 2) shows three main zones exhibiting different origin and style of tectonic deformation. The central zone exhibits the Esperanza basin, which developed south of the Posorja detachment system (PDS). The Domito fault system (DFS) and the Puná-Santa Clara fault system (PSCFS) bound this basin to the west and to the east, respectively. The Jambelí basin develops east of the
PSCFS. The Jambelí detachment system (JDS) bounds the Jambelí basin to the south. The upper continental slope extends west of the DFS.

\subsection{Posorja Detachment System}

[11] The Posorja detachment system (PDS) bounds the Esperanza basin to the north. It corresponds to the boundary between the Santa Elena rise and the Esperanza basin, which separates the Paleocene-early Miocene acoustic basement to the north from the Pliocene-Quaternary basin infill to the south (Figure 2). It exhibits a strong signature on profiles at depth ranging from 2 to $5 \mathrm{~s}$ TWTT. Once corrected for the $\sim 2.5$ vertical exaggeration, this discontinuity dips to the south with an angle of about $20^{\circ}$. The seismic profiles reveal that the direction of the PDS changes from E-W to NE-SW along trend. A southward increasing subsidence rate and a rollover fold developing to the south is associated with the development of this major tectonic discontinuity. Consequently, the PDS is a low-angle flat ramp. The seismic profiles show that this detachment controlled the subsidence all along the system during the Quaternary. The subsidence is limited to the west by the DFS and to the east by the PSCFS (Figure 2). Along line 1, the lower series shows a normal drag fold pattern with highest subsidence zones placed close to the discontinuity. This tectonic signature resembles that of a simple normal fault along the NW-SE segments of the PDS (line 1, Figure 4). Along line 2, subsidence is weaker but the highest subsidence of Quaternary series is located away from the tectonic discontinuity suggesting that southward subsidence was controlled by the detachment structure. We consider that high subsidence and normal drag fold subsidence related pattern observed close to the tectonic discontinuity of the PDS along line1 is a local signature related to change in its trending direction. This change in trend possibly plays an important role in the amount of subsidence generated by the PDS at this zone. In contrast, the shallow Quaternary series shows a rollover reverse drag fold pattern (lines 1 and 2). We assume that this tectonic feature is related to the major dip change of the detachment from subhorizontal to the north to about $20^{\circ}$ to the south making necessary the rollover fold to develop. The rollover folding placed above the horizontal surface along line 1 probably results from the slip of an eastern or northern fault. Even so this fault has not been observed in seismic lines. The northern flank of the rollover fold is characterized by the development of normal faults (lines 1 and 2). These faults located above the flat ramp of the detachment accommodate the rollover deformation in this area. Because global compilations of normal fault focal mechanisms show only a small fraction of events with nodal plane dipping less than $30^{\circ}$, doubt persists that faults either initiate or slip at shallow dips. However, geologic reconstructions and seismic reflection profiling indicate that initiation and slip on low-angle normal faults in the upper crust are common in the geologic record [i.e., Wernicke, 1981; Angelier and Coletta, 1983; Spencer, 1984; Buck, 1988].

[12] The deeper series observed along the seismic profiles along the western part of the PDS (lines 1 and 2) tend to 

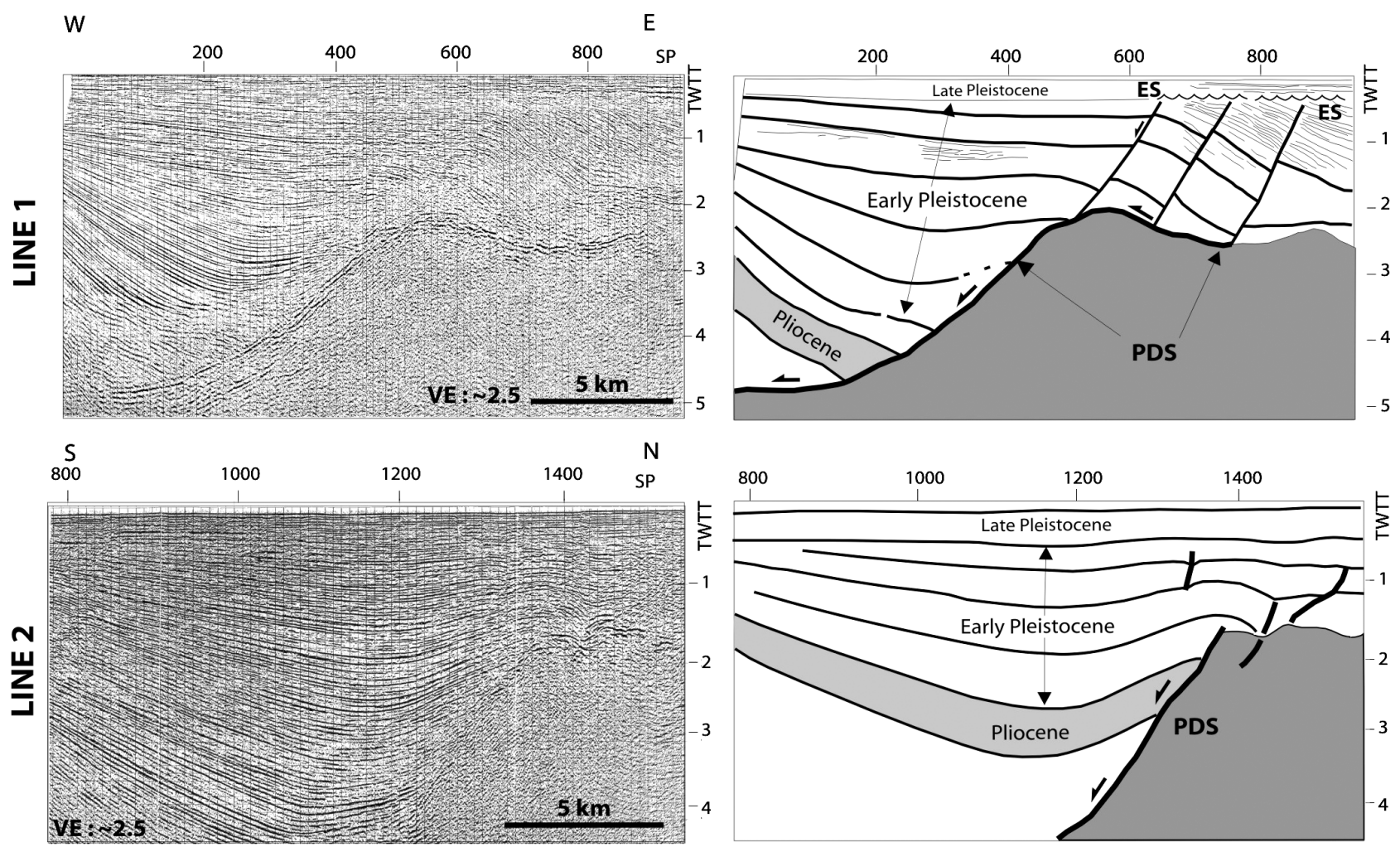

Figure 4. Posorja detachment system (PDS). (top) Line 1. Note that the development of the PDS controlled the accumulation of sediment along the hanging wall. Also a rollover fold developed as the flat ramp of the detachment developed. The late Pleistocene unconformably overlies the rollover fold. The ES unconformity is associated with an exposure occurring during the isotope substage 6 low stand. No active subsidence related to the detachment is observed above the ES unconformity. (bottom) Line 2. Thickening of the syntectonic sequences show that the flat ramp of the PDS was mainly active during the early Pleistocene. Note the presence of a rollover fold. Dark grey shows the basement (i.e., Paleoceneearly Miocene sequence of the Santa Elena rise). Light grey shows the Pliocene. ES, exposure surface, unconformity. See Figure 2 for location of lines.

thicken near the ramp, indicating that sedimentation occurred during tectonic deformation along the detachment. This began possibly during the Pliocene (the Pliocene series along line 1 lies on the zone where seismic reflections become unclear) in the western part of the system. To the east (line 2) the Pliocene shows no thickness variation. The main subsidence event took place in the early Pleistocene. Because the late Pleistocene unconformably overlies (ES in Figure 4) the related rollover fold deformation, we consider that the PDS has no significant activity since that time.

[13] A thinner sequence of late Pleistocene age unconformably overlies the thick syntectonic sediment accumulation. We assume that after this episode the PDS shows no significant activity. Even so, minor extensional activity has been observed in the segment placed near the Puná island (Figure 2). There, the observed deformation is not related to the detachment but to a growth fault that developed between the flat ramp and the sedimentary cover.

\subsection{Jambelí Detachment System}

[14] The Jambelí detachment system (JDS) and the associated Jambelí basin (Figure 2) are characterized by a complex array of old (pre-Quaternary) and recent structures. The projection of data from the Tiburon 1 well to the east and the seismic facies interpretation from line to line allows us to identify the Jambelí basin basement to be probably of Paleocene-early Miocene age. The base of the early Pleistocene facies has been projected from the Amistad Sur 1 well, using N-E and N-W trending seismic lines (line 5, Figure 5).

[15] The JDS includes two major faults: a southern normal fault and a northern low-angle slip surface both dipping to the north. The northern fault (i.e., the Puerto Balao fault) connects the detachment at depth (line 3). The Jambelí basin exhibits a $2-3 \mathrm{~km}$ thick accumulation of sediment. This accumulation is mainly controlled by the Puerto Balao fault development. The Puerto Balao fault shows a complex geometry. In line 3 it dips almost vertically close to the seafloor. It flattens downward to be almost horizontal as it connects to the southern segment at depth. The Puerto Balao fault marks the southern limit of the main early Pleistocene subsidence in the Jambelí basin. Along this fault, subsidence is also controlled by a series of antithetic normal faults developing above the active slip 

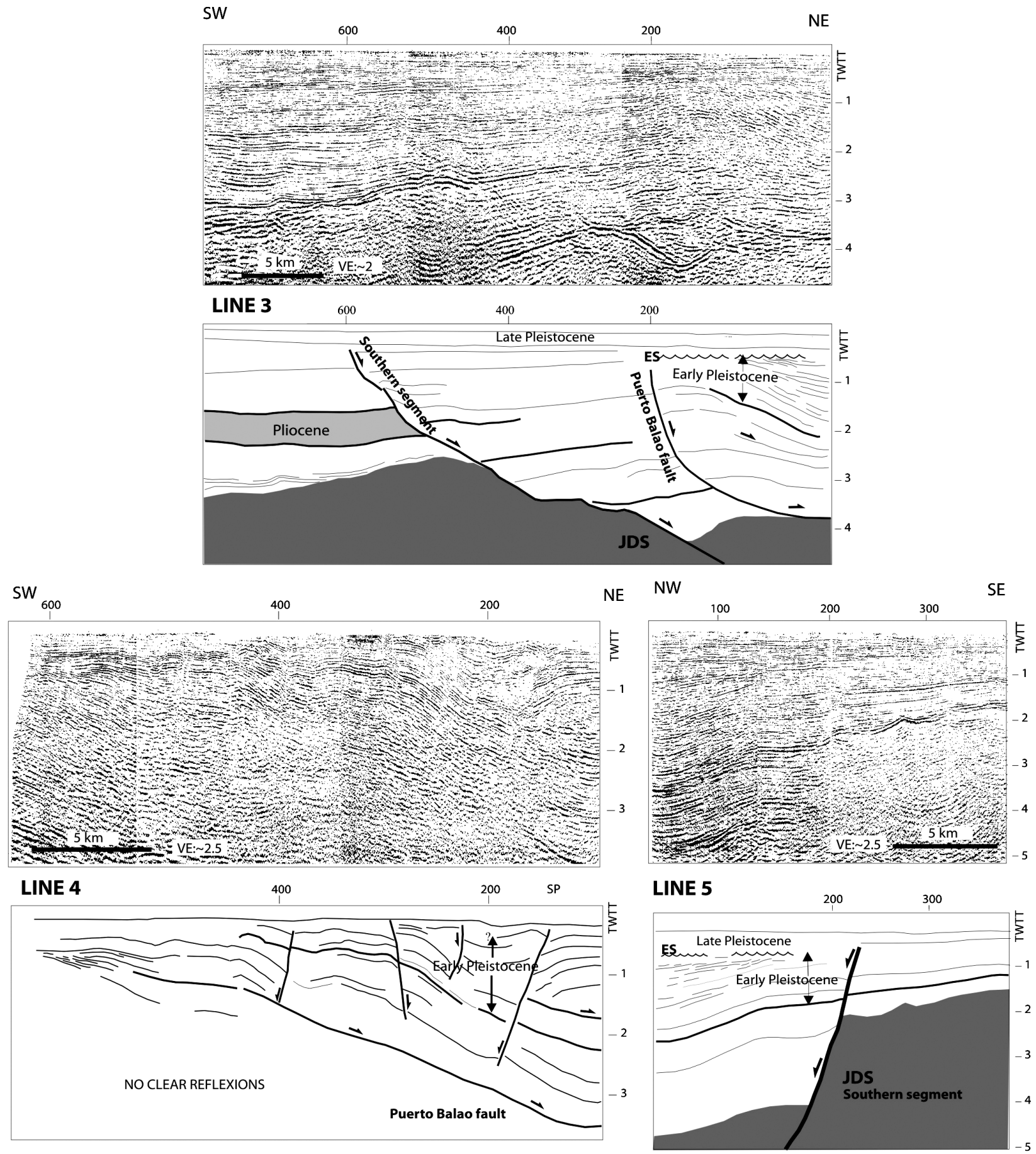

Figure 5. Jambelí detachment system (JDS). (top) Line 3. Age interpretation is from Amistad Sur 1 well data projected to the Jambelí area. Main subsidence phase occurred during the early Pleistocene times. (bottom left) Line 4, rollover folding developed in association with the flat ramp of the JDS. Note that the synthetic and antithetic faults only developed above the flat ramps. (bottom right) Line 5, note the ES unconformity that is coeval with that identified along line 3. Dark grey shows the basement. Light grey shows the Pliocene. ES, exposure surface, unconformity. See Figure 2 for location of lines. 
zone (line 4). Also rollover folds developed in these areas of high subsidence rate indicating the presence of low-angle slip working at depth (lines 3 and 4). The sites showing the highest subsidence are those located in the limit between the offshore and onshore seismic lines enhancing a lack of data that prevents an accurate analysis of this zone.

[16] The southern fault of the JDS exhibits an E-W trending direction, roughly parallel to the Puerto Balao fault (Figure 2). The almost horizontal attitude of the sedimentary sequences located between the two faults (line 3 ) reflects the low tectonic activity of the southern segment. The recent activity of this southern segment is characterized by lowamplitude vertical displacement, which is associated with low subsidence in the sedimentary cover (lines 3 and 5, Figure 5). On the other hand, the basement of the Jambelí basin exhibits a greater displacement along the fault (lines 3 and 5, Figure 5). The difference in displacement observed between the recent and older sequences is possibly related to a recent reactivation of the fault in the early Pleistocene (Figure 5). Subsequently, no tectonic deformation exists during the development of an erosional unconformity (ES in lines 3 and 5, Figure 5) overlying older sequences. This unconformity is associated with a general subaerial exposure of the GG area occurring between 182 and $329 \mathrm{ka}$ (section 5.2).

\subsection{Puná-Santa Clara Fault System}

[17] On the basis of the available seismic profiles, we have identified three main segments along the Puná-Santa Clara fault system (PSCFS), from NE to SW it includes (Figure 2): the Puná segment, the Santa Clara platform segment, and the southern Amistad structure.

[18] To the north, along the Puná segment, the PSCFS shows weak compressional deformation (line 6, Figure 6). The deeper sequences show no syntectonic features related to the formation of this structure, indicating that deformation began recently. No evidence exists onshore for the PSCFS having a prolongation to the north. Northeast of the Puná island the seismic profiles show an elongated 5$7 \mathrm{~km}$ wide nonreflective zone (Figure 2). Close to this zone the acoustic signature of the upper layers (profile not shown) shows major tectonic disruption also suggesting that recent compressive activity occurred. The seismic profiles allowed us to follow this nonreflective zone (Figure 2) to the south, across the Puná island and below the Zambapala mountain range (300 $\mathrm{m}$ above sea level). Unfortunately, the loss of seismic reflections and the uncertain correlation with the ages obtained from well data prevent constraining properly the chronology of the tectonic activity within the area.

[19] Southward, along the segment of the Santa Clara platform (Figure 2) the seismic profiles reveal a pop-up compressional structure (line 7, Figure 6). At that site, the seafloor exhibits a 4-17 $\mathrm{m}$ high scarp, indicating that the structure is active. On either side of the PSCFS, the thickness of the early Pleistocene-Pliocene sequences shows no significant variation, suggesting that the pop-up structure formed afterward. Because the syntectonic on-lap deposits, unconformably overlying the raised series, are of late
Pleistocene age, we assume that deformation began at the early late Pleistocene boundary.

[20] The southern prolongation of the PSCFS corresponds to an antiform, the so-called Amistad structure (line 8, Figure 7). No Pliocene thickness variation is observed crossing of the Amistad structure documenting that no significant tectonic activity existed during the Pliocene at that site (lines 8, 9, and 10, Figure 7). Paleontological markers from the Amistad Sur 1 well, combined with seismic facies signatures; show that Quaternary subsidence was more important west of the structure than to the east. Instead to record the tectonic activity of the PSCFS, this variation in thickness recorded the subsidence history of the Esperanza basin that began in the early Pleistocene. Indeed, the western segments of lines 8 and 9 (Figures 2 and 7) are located at the eastern edge of the Esperanza basin. The late Pleistocene on-lap sedimentation unconformably overlying raised up series of early Pleistocene age (line 8, Figure 7) documents a compressional tectonic event that affected this basin limit at the early late Pleistocene boundary. More to the south (line 9, Figure 7), as the antiform broadens the on-lap syntectonic deposits thin, which suggests that the edge of the basin is almost not affected by the late Pleistocene compressional deformation at that site. The southernmost profile (line 10, Figure 7) shows that no deformation exists in this area. At this point, the southern edge of the Esperanza basin has no clear expression. The main activity of the PSCFS has taken place during the Quaternary. At that time the tectonic activity along the Amistad structure propagates $6-7 \mathrm{~km}$ to the south in a gentle flexure structure. Three to four $\mathrm{km}$ to the south, line 10 shows no tectonic structure or sediment thickness variation in the prolongation of the Amistad structure. Therefore the PSCFS exhibits no prolongation south of $\sim 3^{\circ} 25^{\prime} \mathrm{S}$.

\subsection{Esperanza Graben}

[21] The Esperanza graben is located in the central part of the GG area. It trends roughly perpendicular to the PSCFS and the DFS (Figure 2). The Esperanza graben is bounded to the north and to the south by a series of major normal faults dipping toward the graben axis (line 11, Figure 8). The trend of the system changes from ESE to the west to ENE to the east. The faults that limit the graben are among the most active tectonic features in the GG area. Also, these faults record the most significant dip-slip component observed from the available data. This graben is the area of the GG where subsidence was the second greatest. Here the Quaternary series are more than $3000 \mathrm{~m}$ thick. During the late Pleistocene, no tectonic inversion is observed along the faults bounding the graben. An antiform trending approximately E-W developed between the active limits of the graben. The uniform thickness of the Pliocene throughout the graben area (line 11) associated with the early Pleistocene highest subsidence rates along faults indicate that this antiform formed during the early Pleistocene time. Because this antiform is associated with major normal faults we assume that it develops either as a rollover 

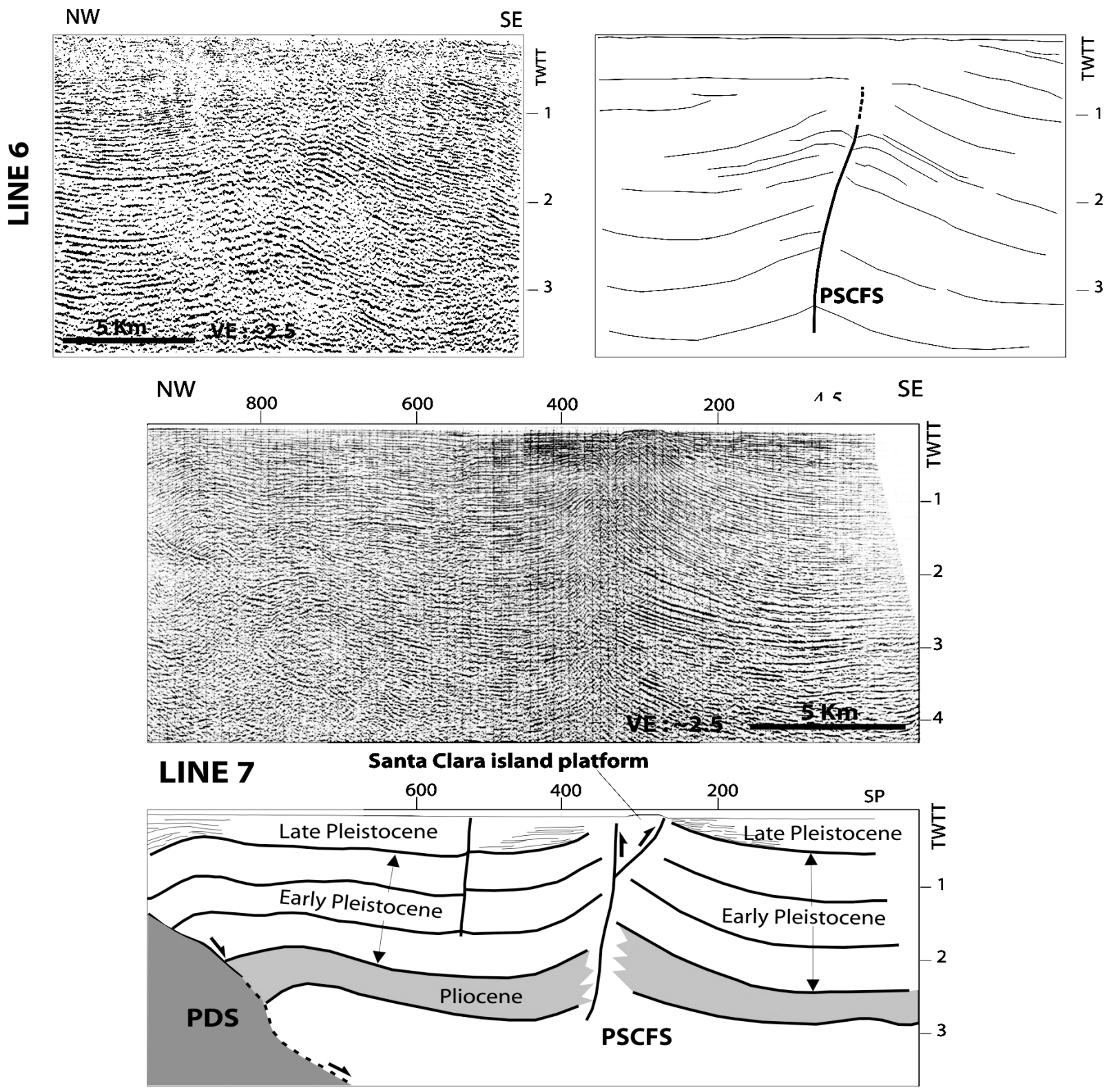

Figure 6. Puná-Santa Clara fault system (PSCFS). (top) Line 6, northeastern segment of PSCFS. No age correlation is possible in this area. Seismic record shows moderate contraction. The lost of seismic signal upward prevents to characterize the most recent deformation. Sequences show no variation in thickness on either side of the PSCFS suggesting that tectonic deformation occurred recently. (bottom) Line 7, the Santa Clara island segment of PSCFS. The thickness of the Pliocene-early Pleistocene sequence shows no variation crossing the fault system. Fault activity began in the late Pleistocene. The rollover fold to the NW is related to the PDS development. Dark grey shows the basement. Light grey shows the Pliocene. See Figure 2 for location of lines.

fold along a detachment fault at depth or as the signature of a lateral strike-slip component along the normal faults bounding the graben.

\subsection{Tenguel Fault}

[22] The Tenguel fault (line 12, Figure 8) shows a major change of its trending direction, from N-S to the north to E-
$\mathrm{W}$ to the south. It is a normal fault and its evolution is recorded by $3600 \mathrm{~m}$ of Quaternary sediments. This is the highest sedimentation rate known in the GG area. The seismic profile (line 12, Figure 8) exhibits at least two faults. A scarp on the seafloor indicating that tectonic deformation is active underlines the main fault to the west. The two faults together and an antiform feature placed between them form a positive flower type structure located 

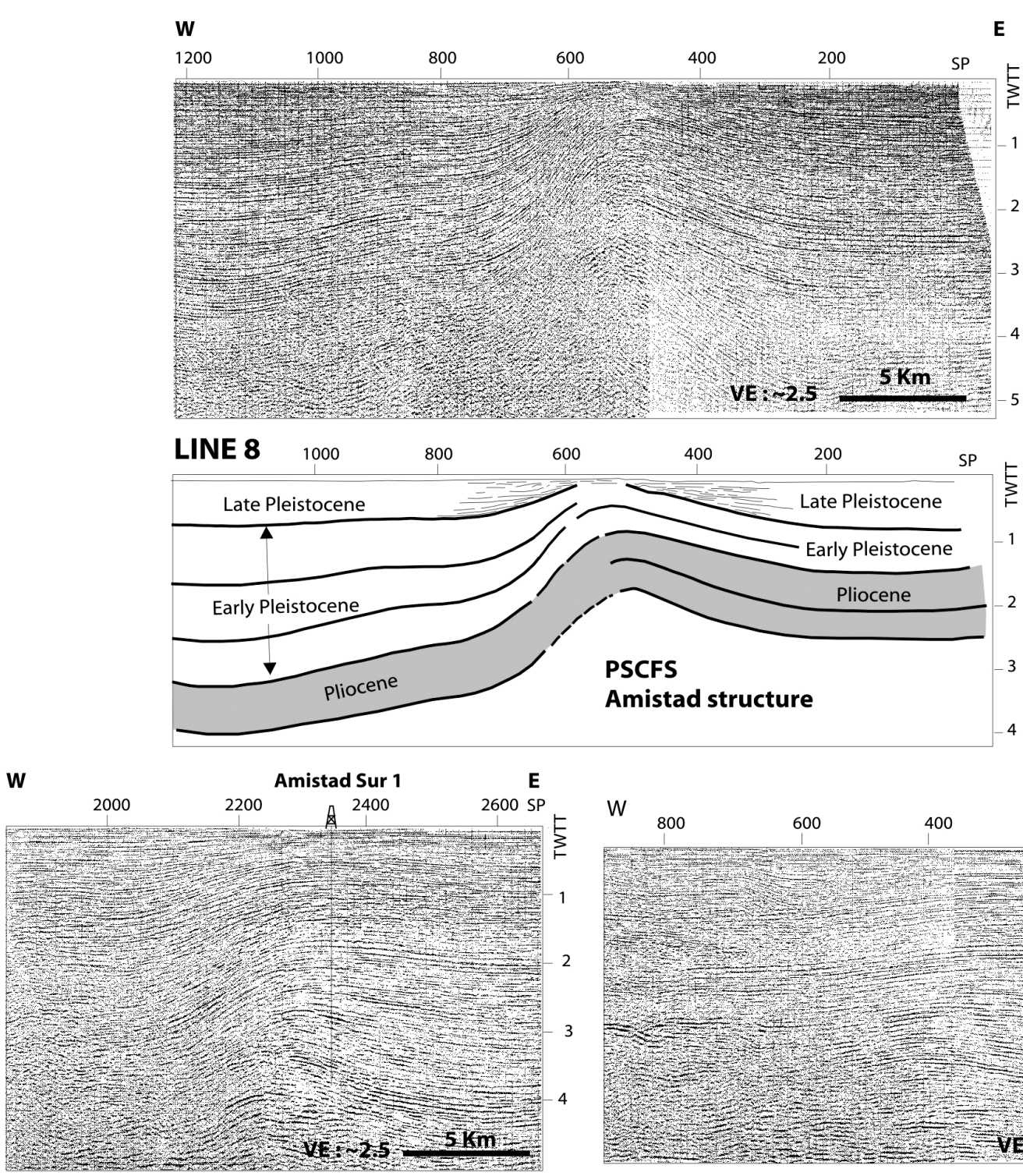

\section{LINE 9}

$2200 \quad A^{2400}$

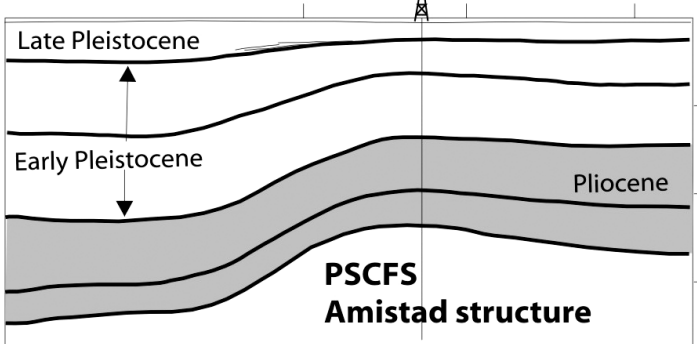

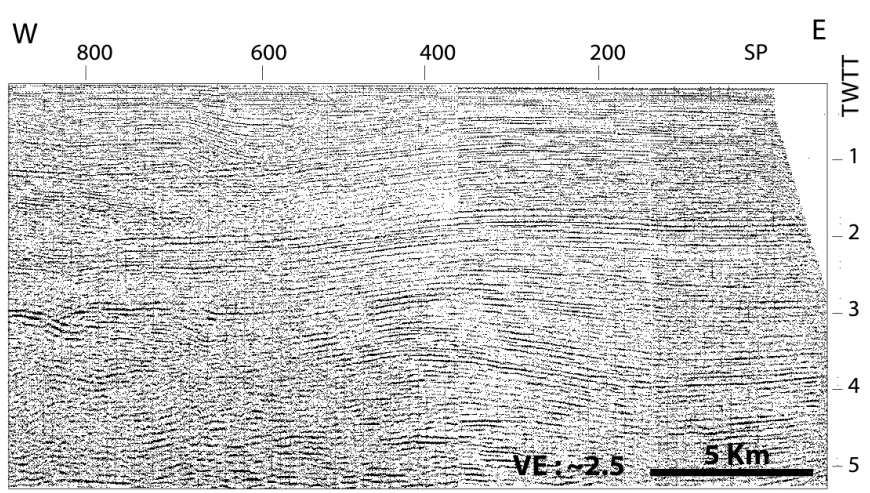

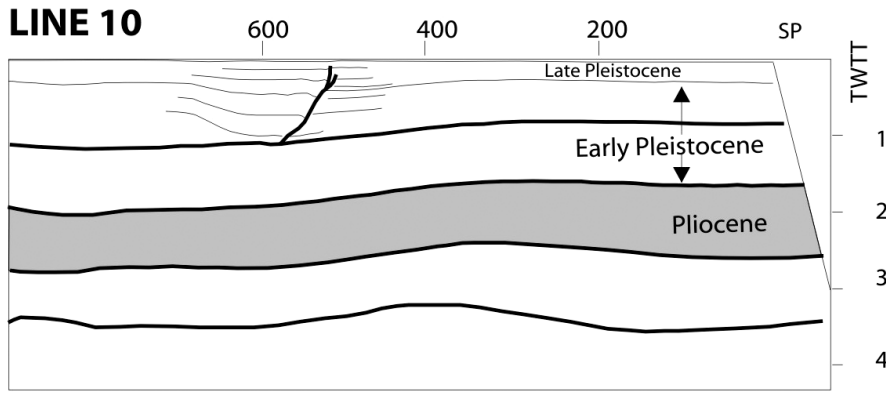

Figure 7. Southern segment of the Puná-Santa Clara fault system (PSCFS). (top) Line 8. The so-called Amistad structure shows no significant variation in thickness of the Pliocene sediment, the antiform structure formed afterward. (bottom left) Line 9. The Amistad structure flattens southward. (bottom right) Line 10. More to the south, no tectonic deformation exists in the prolongation of the Amistad structure. See Figure 2 for location of lines. 
S
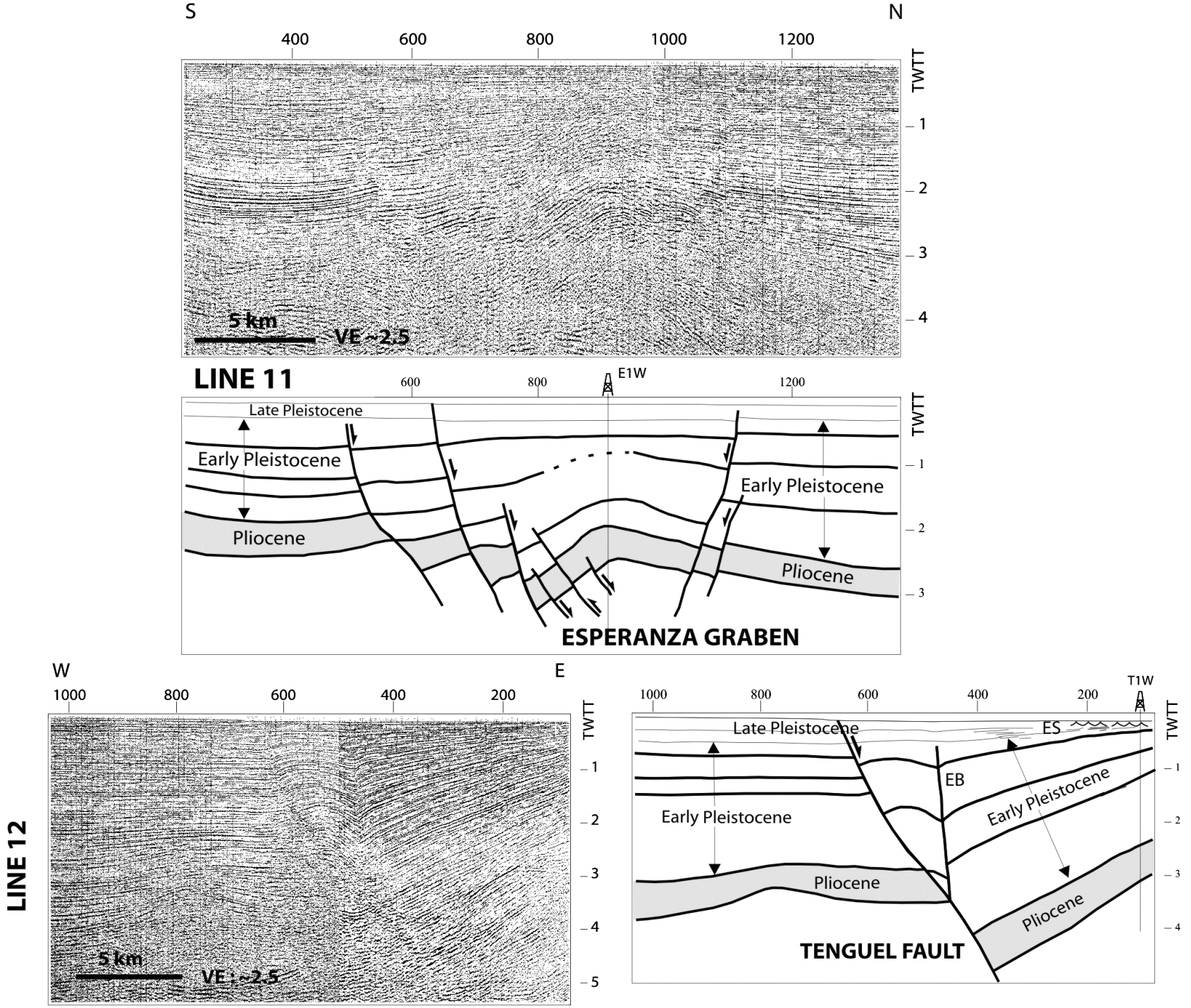

Figure 8. Esperanza graben and the Tenguel fault. (top) Line 11. The syntectonic series are of early Pleistocene age. Note the antiform at the center of the line. It may originate either from strike-slip induced deformation or rollover folding related to PDS at depth. Age controls are from the industrial E1 well located $8 \mathrm{~km}$ off line. (bottom) Line 12. The Tenguel fault evolved as a normal fault during the early Pleistocene. The vertical eastern branch of the fault (EB) possibly originated from late Pleistocene compression. At Present, the Tenguel fault is under tensional stress. Age controls are from the industrial T1 well located $8 \mathrm{~km}$ off line. ES, exposure surface, unconformity. See Figure 2 for location of lines.

in the central part of the system. The Tenguel fault evolved through three tectonic episodes:

[23] 1. During the early Pleistocene the southwestward dropping and the thickened sedimentary series close to the Tenguel fault suggest that a major normal faulting event occurred. The main accumulation of sediment occurred at that time as the flat normal Tenguel fault evolved.

[24] 2. The formation of the antiform occurred in late Pleistocene times. This feature is associated with a transpressive component of deformation along the Tenguel fault and/or to space problems arising during downward movement of the hanging wall block. This effect is probably due to the curvature of the fault at depth and to the drastic change in trend which push-up the hanging wall block (Figures 2 and 8). Seismic lines do not allow us to constraint a single model for the antiform formation. Even so, if there is a compressive episode, the compressive deformation does not significantly displace reflections as compared to the $\sim 1 \mathrm{~km}$ down throw, which occurred during the previous tensional episode. The tectonic inversion episode is a local and minor event.

[25] 3. Subsequently, an extensional tectonic episode occurred along the Tenguel fault. This tectonic event is associated with the development of a normal fault, which 
displaced the seafloor along an 11 to $40 \mathrm{~m}$ high scarp. This suggests that extensional processes controlled the tectonic evolution of the Tenguel fault during the late Pleistocene. The Tenguel fault, located above the PDS, appears as a second-order tectonic feature associated with the first-order PDS located at depth. We consider that the Tenguel fault is an antithetic tectonic feature that developed in close associated with the PDS at depth.

\subsection{Domito Fault System}

[26] The Domito fault system (DFS) is roughly located along the shelf break, which bounds to the west the continental platform from the upper continental slope. Also, it marks the limit of the Esperanza basin to the west (Figures 2 and 9). Westward, from the DFS, the continental slope exhibits a series of N-S trending structures with strong signature both in bathymetric and seismic records. These seaward dipping tectonic features are listric normal faults (lines 13 and 14, Figure 9) accommodating the tensional tectonic regime along this area. The tectonic style and deformation along the continental slope is different than those identified to the east along the Esperanza basin.

[27] Along the DFS the deepest deformed reflectors in the northern part of the system are observed at 3.5-4 s TWTT below seafloor. The thickening of the sedimentary sequences toward the DFS indicates the occurrence of syntectonic sedimentation suggesting that this fault system was mainly active during Miocene to Pliocene time (lines 13 and 14, Figure 9). To the south, close to the Peru-Ecuador border, the eastern fault of the DFS is associated with a N-S trending fold. We suggest that strike-slip motion occurred along the fault (Figure 2). The roughly N-S trending PSCFS and DFS bound the Esperanza basin to the east and to the west, respectively. As the PSCFS, the DFS acted as a transfer fault during Pleistocene time. Evidences including the presence of seafloor escarpments along the DFS show that the system is active at Present.

[28] Several mud diapirs exist along the seaward break of the continental platform (line 15, Figure 9). These mud diapirs underline the DFS. Instead of being related to the fault zone, Deniaud et al. [1999] proposed that the emplacement of the diapirs originated from Quaternary sediment having high sedimentation rate. We found no direct relationship between the zones of high Quaternary subsidence rate and the emplacement of the diapirs. As a matter of fact no diapirs are observed in areas of highest subsidence rates (i.e., inside the Esperanza basin). The diapirs are only observed along the upper continental slope, and their emplacement is tectonically controlled by N-S trending normal faults. The roots of the diapirs are not identified in the seismic lines, indicating that the undercompacted mud material from which they originated is located deeper than $5 \mathrm{~s}$ TWTT below seafloor (i.e., deeper than 5000-6000 m below seafloor). Deep marine multichannel seismic reflection profiles acquired across the western part of the GG and the continental platform [Collot et al., 2002] show that diapirs possibly root at the main unconformity between the basement and the sedimentary cover at 6-8 s TWTT depth below seafloor [Calahorrano,
2005]. None of the diapirs identified in this area pierce through to the seafloor suggesting that the process is currently inactive (line 15, Figure 9). Because the late Pleistocene unconformably overlies the diapir structures, they probably remained inactive since that time.

\section{Gulf of Guayaquil Area Evolution}

[29] During the Miocene-Pliocene the GG shelf-slope break was probably located farther east than today. The N-S trending DFS and associated seaward dipping normal faults (line 14, Figure 9) that controlled the high subsidence rate were situated along the upper and middle continental slopes during this period. The 2 to $7 \mathrm{~s}$ TWTT thick MioPliocene (or older) sediment identified in this area recorded an E-W trending tensional tectonic step (Figure 10a). This tectonic regime that induced trench parallel seaward dipping normal faults is widely recognized along active margins where subduction-erosion is working at depth [Scholl et al., 1980; Bourgois et al., 1984, 1988; von Huene and Scholl, 1991]. In this western area of the GG, we assume that subduction related processes controlled sediment accumulation during the Mio-Pliocene time. Indeed subsidence was active along the DFS at least since the late Miocene. Moreover, evidences show that the DFS connects southward to Banco Peru and farther south to the Talara detachment [Witt et al., 2006] both structures being associated with westward dipping N-S trending normal faults. Along the northern Peruvian margin subduction erosion working at depth has been considered as the driving mechanism of subsidence of the continental margin since the middle Miocene [von Huene et al., 1988]. The tectonic regime identified along the continental margin of southern Ecuador (off the Gulf of Guayaquil) extended farther to the south off northern Peru.

[30] On the basis of the occurrence of Mio-Pliocene series in well data, Benitez [1995] proposed a Mio-Pliocene age for the GG area opening. However, the model of Benitez [1995] was not supported by seismic data. The Pliocene sediment accumulation shows no major difference in thickness throughout the GG area, suggesting that most of the major tectonic features, which characterize the area, were inactive during the Pliocene (Figure 10a). Calahorrano [2005] reached the same conclusion using $15 \mathrm{~s}$ TWTT length MCS records acquired along the western Esperanza basin area during the Sisteur cruise [Collot et al., 2002]. The synrift series along the Esperanza basin traverse are of early Pleistocene age.

[31] However, along seismic lines a weak opening pulse of the Esperanza basin occurred locally during Pliocene time. It is recorded along the PDS western segment (Figure 10a) showing a low subsidence rate and is likely not related to the PSCFS. Indeed, we found no evidence for the PSCFS to exist at that time. Minor subsidence events are also observed along what will be the JDS. This period of minor Pliocene subsidence was also observed by Deniaud et al. [1999].

[32] Regarding the pre-Quaternary evolution, well data of the GG area (Figures 2 and 3) show that the Miocene and 

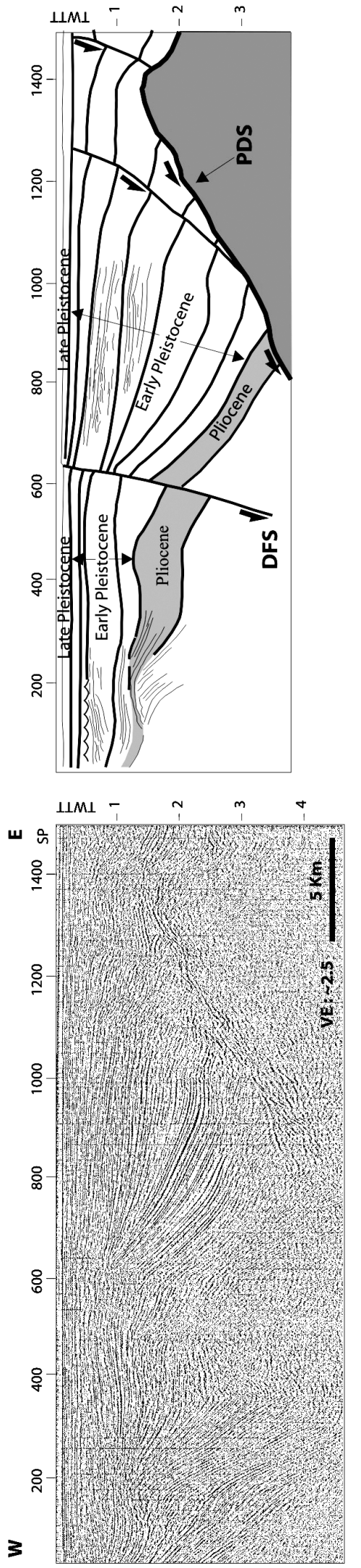

EL $\exists N I T$
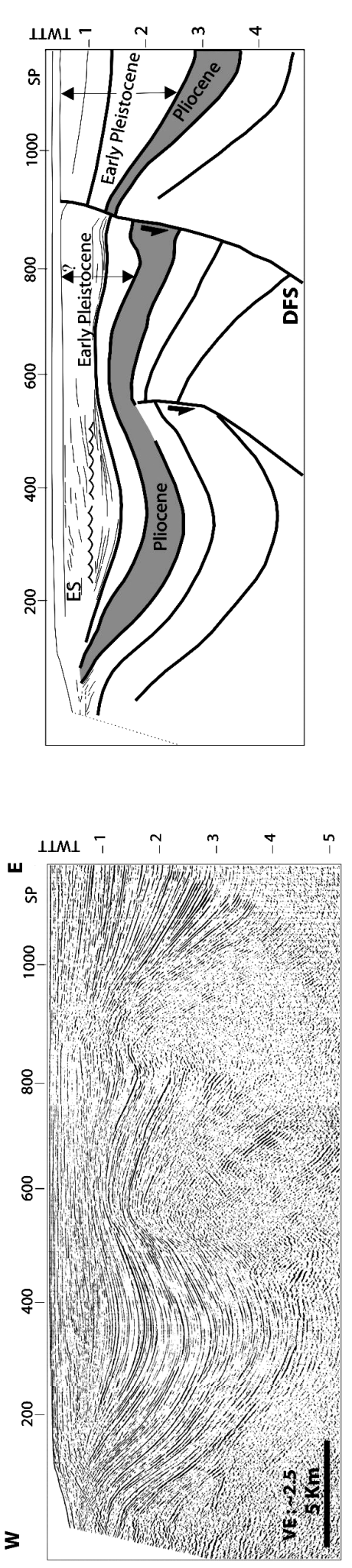

†L $\exists N I 7$
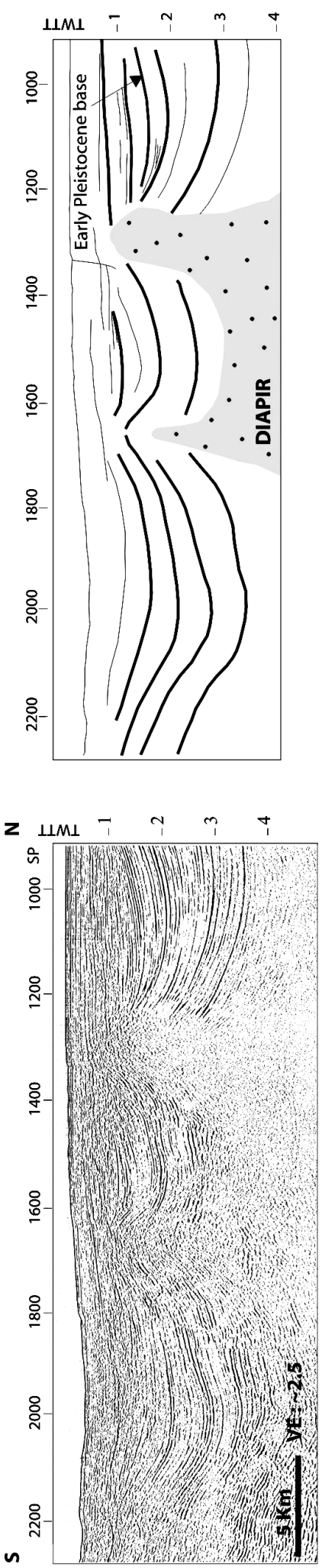

SL JNIT

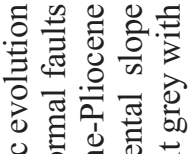

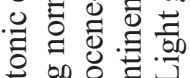

过

鹤

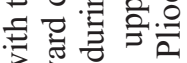

昰总导

离売志

के

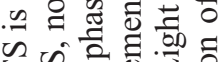

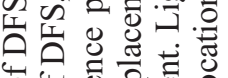

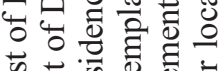

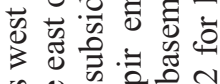

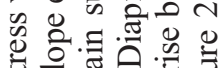

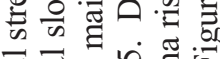

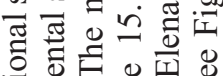

ज.

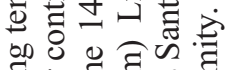

寻志

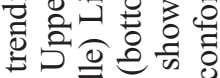

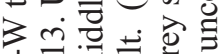

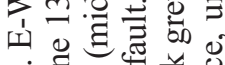

क्ञ

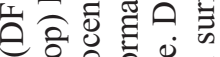

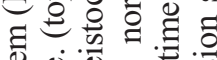

के

忿运可.

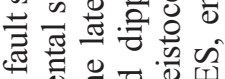

훰웜

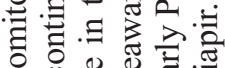

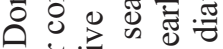

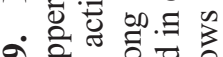

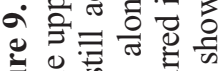

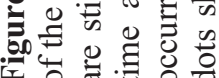


PRE-QUATERNARY

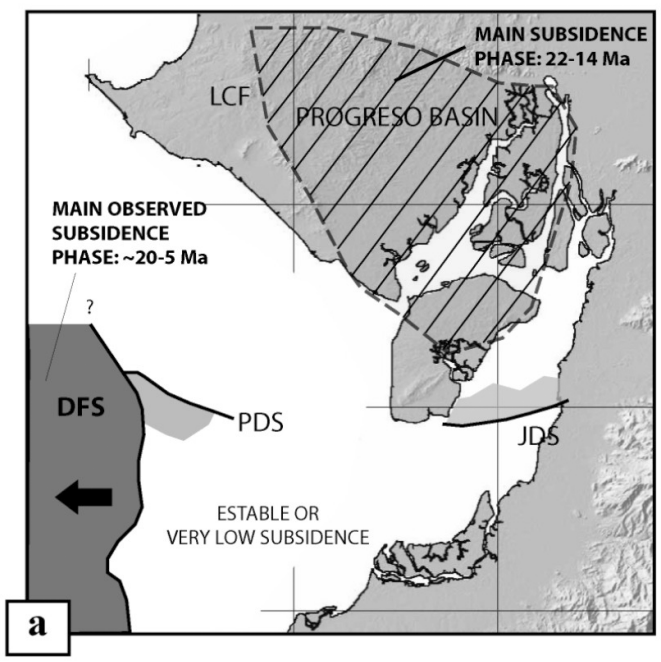

$180 \mathrm{ka}-140 \mathrm{ka}$

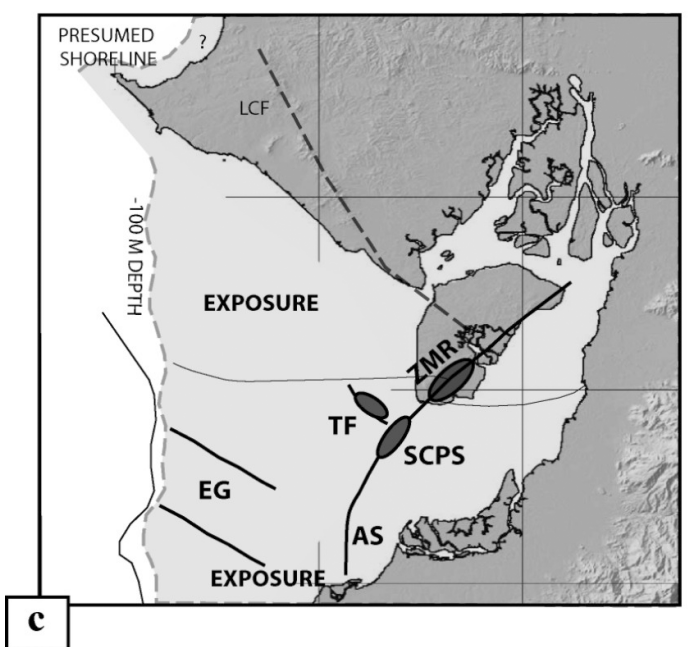

EARLY PLEISTOCENE (1.8-1.6 Ma to 0.18 Ma)

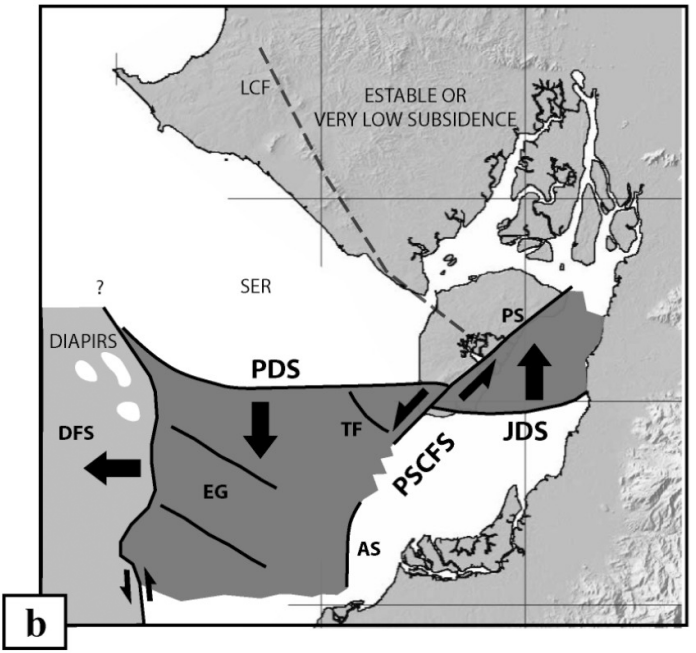

PRESENT

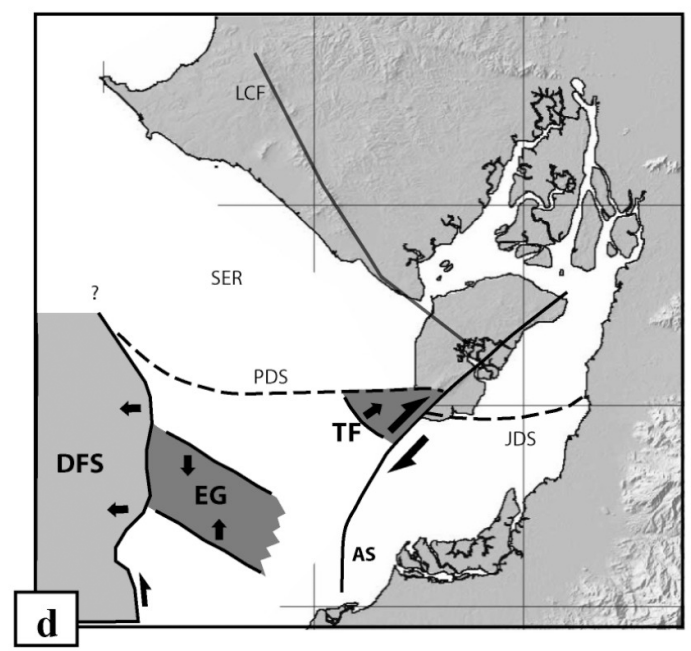

\footnotetext{
High subsidence rate

Low subsidence rate

Tectonic inversion - uplifted series

1/. Strike slip fault, transfer fault Subsidence direction
}

Figure 10. Reconstruction of the tectonic history of the GG area. The coastline is considered only as a geographic reference frame. Dashed line shows the currently inactive features. (a) Pre-Quaternary time, main subsidence periods are shown; (b) early Pleistocene time; (c) Exposure of the GG area during isotope substage 6 low stand; and (d) Present time. DFS, Domito fault system; EG, Esperanza graben; JDS, Jambelí detachment system; LCF, La Cruz fault; PDS, Posorja detachment system; PSCFS, PunáSanta Clara fault system (including AS, Amistad structure; PS, Puná segment; SCPS, Santa Clara platform segment; ZMR, Zambapala mountain range); SER, Santa Elena rise; TF, Tenguel fault. See text for more detail. 
Pliocene facies described along the Progreso forearc basin (Figure 1) extend southward along the GG area, including below the thick Quaternary sediment, which accumulated along the Esperanza basin. It is of importance to note that the paroxysm of subsidence along the Progreso basin is significantly older than along the GG area. Main subsidence-related sedimentation rates along the Progreso basin occurred during $\sim 23-14$ Ma [Benitez, 1995; Deniaud, 2000]. Subsequently, a stable or very low subsidence period is installed from $14 \mathrm{Ma}$ to present times, a period during which NAB drifting probably begins [Winkler et al., 2005]. Even so, minor change occurred during the Pliocene, the stable subsidence phase of the GG area was from $\sim 5$ to $\sim 2 \mathrm{Ma}$ [Deniaud, 2000]. At $2 \mathrm{Ma}$ the subsidence-related sediment accumulation rate increased drastically being $\sim 6$ times greater than that recorded during the Pliocene. In comparison with the Progresso basin, the GG sediment accumulation rate during the Quaternary is 3-5 and 20 times greater for the Miocene $(23-14 \mathrm{Ma})$ and the Quaternary times, respectively. High subsidence rate along the GG during the Quaternary define the most important tectonic event in the Ecuadorian forearc for at least the past $10 \mathrm{Myr}$. To consider that the GG developed above a precursor Progreso basin, or if the Domito fault system extended landward, cannot be resolved with our seismic lines. However, we consider that the major change in the subsidence and deformation style during the early Pleistocene time is the signature of a major reorganization along the NAB southern limits.

[33] It is possible that the major geodynamic reorganization of Pleistocene-Holocene age documented along the GG area extended to the north across the Progresso basin area. However, the reorganization along the Progreso basin was much less significant than along the GG area where the major PDS slip motion maintained the GG area below sea level. This evolution of the GG area developed through three main tectonosedimentary steps: the first one and the last one characterized by major extensional tectonic events and high subsidence-sediment accumulation rates and the second one by an extensive and short-lived emergence of the GG area in relation with an eustatic sea level low stand.

\subsection{Early Pleistocene Step}

[34] Major subsidence in the GG area occurred during the early Pleistocene. Along the Esperanza basin the southward dipping PDS controlled this subsidence phase. The early Pleistocene subsidence phase identified in the Jambelí basin developed in relation to the northward dipping JDS. This major flat detachment dips in the opposite direction to that of the PDS (Figure 10b). Therefore during Pleistocene time, the Puná segment of the PSCFS has to develop as a transfer fault (PS in Figure 10b) in order to accommodate the opposite motion of the two opposite verging detachment systems. The maximum of tectonic deformation to accommodate the transfer of motion from one side to another has to be located along the segment of PSCFS, which connects the two detachments (i.e., along the Zambapala mountain range of the southern Puná island, Figure 2). Indeed this segment of the PSCFS is the site of major deformation as evidenced by the loss of reflections over a 5-7 $\mathrm{km}$ wide corridor following the PSCFS across southern Puná island (Figure 2). This strip of tectonic deformation, deeply rooted at depth is interpreted to be a major highly fractured zone that defines a left-lateral transform zone. Unfortunately, no age can be projected from the Fel well data to this zone due to the loss of reflections. In accordance with our transfer fault model, the age of deformation along the southern Puná segment of PSCFS must be coeval with the early Pleistocene age of the southward and northward slip motions documented along the two detachment systems.

[35] The Esperanza and Jambelí basins evolved through a $\mathrm{N}-\mathrm{S}$ trending tensional regime. We assume that this regime is related to the NAB northward drifting. The roughly N-S trending PSCFS and DFS bound the Esperanza basin to the east and to the west, respectively. This implies that the DFS participates in the accommodation of the NAB northward drifting. The major depocenters with the highest subsidence rates are controlled by the Tenguel fault and the normal faults, which bound the Esperanza graben. The development of these faults during Pleistocene time was controlled by the PDS at depth.

\subsection{Short Period of Uplift and Exposure}

[36] A pervasive unconformity marks the end of the early Pleistocene subsidence phase, which occurred along the Posorja and Jambelí detachment systems. Early and late Pleistocene are locally used to refer to the sequences located below and above the strong reflections that underline the unconformity. Because about $3000 \mathrm{~m}$ of sediment accumulated during the so-called early Pleistocene in the subsiding zones of the GG area, it is widely accepted that it was about 1 Myr in duration leading to an accumulation rate of $\sim 3 \mathrm{~mm} / \mathrm{yr}$. As a consequence the so-called late Pleistocene would be about $600-800 \mathrm{kyr}$ in duration. Accepting this gross interpretation, we assume that the exposure of the GG area has to occur during one of the four sea level low stand known during the past $600 \mathrm{kyr}$, i.e., at $\sim 21, \sim 140, \sim 350$, and $\sim 450$ kyr [Porter, 1989; Shackleton, 1997; Tzedakis et al., 1997; Lambeck et al., 2002]. During these past glaciations, sea level was lower by $120-140 \mathrm{~m}$ than today. Because these sea level low stands are 30 to $40 \mathrm{kyr}$ in duration [Winograd et al., 1997], we assume that the exposure of the GG area was short in duration, $\sim 20-$ $50 \mathrm{kyr}$ with respect to the location site. West of the Esperanza basin the unconformity is at a depth of $\sim 0.4-$ $0.6 \mathrm{~s}$ TWTT (i.e., $\sim 350$ to $\sim 500 \mathrm{~m}$ ) below seafloor in water depth ranging from 150 to $200 \mathrm{~m}$. Taking into account that sea level was $\sim 140 \mathrm{~m}$ below than today, the unconformity, which underlines the exposure subsided between 310 and $560 \mathrm{~m}$ in this area located more than $100 \mathrm{~km}$ west of the Present coastline. Considering that (1) the NAB escape to the north is recognized as a major leading factor controlling the GG tectonics and (2) the kinematic situation allowing the NAB to drift northward has been stable since the base of the Pleistocene at $\sim 1.6-1.8 \mathrm{Ma}$, we assume that subsidence rate in the GG area has no reason to experience major change originating from kinematics constraint. In addition, the exposure was short in duration. Therefore it makes sense to 
apply to the GG area a main subsidence rate for the past $1.6-$ 1.8 Myr, whether or not it was below sea level. In that way, we calculate that the western Esperanza basin subsided at a mean rate of about $1.7 \mathrm{~mm} / \mathrm{yr}$ since the early Pleistocene time. Using this rate value we infer that the exposure should have occurred between 182 and $329 \mathrm{ka}$. Since glacial sea level falls occurred from 180 to 140 (isotopic substage 6e) and from 380 to $350 \mathrm{ka}$ (isotopic substage 10c), respectively, we assume that the low stand isotopic substage $6 \mathrm{e}$ is the better candidate for the GG area exposure. Indeed the entire GG is $<100 \mathrm{~m}$ depth, it should have been exposed during every glacial maximum (i.e., $\sim 21, \sim 140, \sim 350$, and $\sim 450$ kyr [Porter, 1989; Shackleton, 1997; Tzedakis et al., 1997; Lambeck et al., 2002]). However, only the $\sim 180-140 \mathrm{ka}$ glacial maximum related erosion is observed. This could be explained by the following: (1) other exposure surfaces are not imaged since the frequency used in the industrial seismic lines allows to image the basin architecture at depth and not the sedimentary processes of the shallower series and (2) considering that sea level was 120-140 $\mathrm{m}$ lower than today, it is probable that shorelines involved in the $\sim 21, \sim 350$, and $\sim 450 \mathrm{ka}$ low stands are placed farther west of the available set of lines.

[37] Evidence of compression exists at three zones in the GG area. It includes the Santa Clara platform, the southern Puná island (both located along the PSCFS), and the central segment of the Tenguel fault (Figure 10c). Moreover, marine beds of Pleistocene age were documented on the top of the Zambapala mountain range indicating that uplift of the cordillera occurred afterward [Deniaud et al., 1999; Dumont et al., 2005]. These compressional events, which are roughly coeval with the short-period exposure, show local restricted extension both in space and time. It is difficult to explain the existing compressional tectonic features in the general frame of the kinematics situation with the NAB drifting to the north. In this context, only tensional deformation is expected along the GG area. Because (1) only short segments of the PSCFS and the Tenguel fault show compressional tectonics with low amplitude if compared with the deeply rooted tensional deformation (i.e., low tectonic inversion ratio), (2) no such compressional features exist along other faults trending in the same direction, and (3) subsidence exists along the PDS (line 7, Figure 6) coeval with uplift along the PSCFS at the Santa Clara island platform, we consider that compression observed in the GG area is minor and local. In addition, the structures that exhibit the weak compressive deformation in late Pleistocene times (i.e., Tenguel fault and Santa Clara platform) show a pervasive tensional deformation at Present. We conclude that an extensional stress regime characterizes the Pleistocene evolution of the GG throughout.

\subsection{Postexposure Tectonics}

[38] Currently, tensional tectonic activity takes place along the DFS, the Esperanza graben and the Tenguel fault (Figure 10d). The PDS and JDS show no evidence for ongoing extension today. This process implies a southward migration of the tectonic activity from the PDS to the fault bounding the Esperanza graben to the north. A major reorganization of the basin limits is occurring at Present (Figure 10d). However, minor deformation has been observed along the eastern segment of the PDS. The tectonic activity takes place along a growth fault, which developed between the ramp and the sedimentary cover. We propose that the tectonic deformation associated with this fault is not directly related to the PDS flat ramp, but accommodates the motion produced by the currently active PSCFS and Tenguel fault (Figure 2). Extensional tectonics controls the evolution of the GG area at Present.

[39] It is quite difficult to recognize strike-slip deformation from seismic records because this type of data allows only the vertical motion to be quantified. Moreover, recognition of strike-slip movement may be particularly difficult in young fault systems with small cumulated displacement, where oblique slip or trending slip occurs, and where high rates of contemporaneous sedimentation blankets the evolving deeper structures. This is the case of the PSCFS along which major change in deformation style occurs. It includes seafloor displacements, "pop-up" systems, flower structures and highly fractured vertical zones along trend. These tectonic features demonstrate that the PSCFS is a wrench fault. Taking into account the nature of the detachment zones (i.e., a basement rock along which the sedimentary cover slips) and the slip direction of the detached sedimentary series, we assumed that a left-lateral strike-slip component developed along the southern Puná segment (i.e., between the junction of PDS and JDS with the PSCFS) during the main subsidence phase in early Pleistocene times. Subsequently, the end of the activity along the PDS and JDS modifies the slip direction along the PSCFS. When tectonic activity stopped along the PDS and JDS, the PSCFS accommodated the dextral slip originating from the Tenguel fault, still active at Present. This is in agreement with the right-lateral transtensional deformation during the late Pleistocene described along the Zambapala mountain range [Deniaud et al., 1999; Dumont et al., 2005].

[40] Along the coastal plain southeast of Guayaquil and the Balao area (Figure 2), no morphotectonic feature is identified suggesting that active fault exists in both the northward prolongation of the PSCFS [Eguez et al., 2003] and the eastward prolongation of the two faults of the JDS. We thus assume that the PSCFS and/or the JDS do not connect directly to the Calacalí-Pallatanga fault at present time. The transfer of the partitioning motion between the NAB and the South American plate is not related to a simple fault system cutting across the coastal plain area. In addition, part of the present-day NAB motion must also be accommodated along the seaward side of the continental platform, along the DFS, and across the Esperanza graben.

\section{Discussion}

[41] The NAB northward drifting was proposed to originate from both the obliquity of the convergence between Nazca and South America plates [Ego et al., 1996] and the Carnegie ridge subduction supposed to increase the interplate coupling [Pennington, 1981]. We thus postulate that one of these two factors or both were at the origin of the 
main reorganization occurring south of the NAB (i.e., along the GG area) at the Pliocene-early Pleistocene boundary (i.e., at $~ 1.6-1.8 \mathrm{Ma}$ [Berggreen et al., 1985; Haq et al., 1988; Cande and Kent, 1995]). We also postulate that NAB northward drift exerts important feedback coupling to tectonic behavior and evolution of the GG area. Because no significant plate reorganization has been identified during the past 5 Myr [Pardo-Casas and Molnar, 1987], we assume that no major change in the obliquity of the convergence occurred at $\sim 1.6-1.8 \mathrm{Ma}$. Therefore, accepting seamount subduction as a major factor in the increase of interplate coupling [Cloos, 1992; Scholz and Small, 1997], it is reasonable to accept the Carnegie ridge subduction as the main source of coupling between Nazca and South America plates along the Ecuadorian segment of the PeruChile trench. We thus postulate the Carnegie ridge subduction as being the major factor that induced the NAB northward drifting to increase at the Pliocene-early Pleistocene boundary, and in this manner controlling the GG area evolution.

\subsection{Stress Regime Evolution}

[42] Along the continental margin west of the GG, we document a pervasive Miocene-Pleistocene extensional tectonics associated with seaward dipping normal faults paralleling the N-S trending DFS. This normal faulting along active margins is considered as the signature of subduction erosion working at depth [Scholl et al., 1980; Aubouin et al., 1982, 1984; Bourgois et al., 1984, 1988; von Huene et al., 1989; von Huene and Scholl, 1991].

[43] In early Pleistocene times the subsidence in the Esperanza and Jambelí basins began. The N-S verging detachment structures related to the northward escape of the NAB triggered off the subsidence. Consequently, the DFS marks the limit between a zone strongly controlled by margin processes along the upper continental slope and the continental platform controlled by the northward tectonic escape of the NAB. This reflects that part of the partitioning motion is accommodated along the DFS.

[44] The major period of deformation in the GG area occurred in early Pleistocene times. At that time a major change in the tensional stress regime occurred from $\sim \mathrm{E}-\mathrm{W}$ (DFS) to $\sim \mathrm{N}-\mathrm{S}$ (PDS and JDS) inducing a major reorganization of the NAB southern limits. Accepting that the subsidence along the GG area is controlled by the northward drifting of the NAB during Quaternary times, we thus conclude that the Pliocene-early Pleistocene boundary is associated with a major increase in the northward migration rate of the NAB.

\subsection{North Andean Block Drifting}

[45] Tectonic models suggest that the obliquity vector of convergence between the Nazca and South America plates is not fully partitioned throughout the NAB and that the Caribbean plate influenced mainly the area north of $5^{\circ} \mathrm{N}$ [Ego et al., 1996; Taboada et al., 2000; Corredor, 2003; Acosta et al., 2004; Cortés et al., 2005]. The zone of transition being placed along a major seismically defined E-W transform zone at $\sim 5^{\circ} \mathrm{N}$ coincident with the Baudo range (Figure 1a) [Taboada et al., 2000]. If only the region south of $5^{\circ} \mathrm{N}$ is influenced by the Nazca plate oblique convergence, which induces a right-lateral stress regime (i.e., northward drifting of the NAB) the accommodation of the deformation is more complicated than that involved in a single block moving northward as proposed from GPS data [Trenkamp et al., 2002]. Our data do not allow us to speculate the northernmost extensions of the NAB. For this reason, we only correlate the evolution of the GG area with the proposed NAB limits south of the postulated [Taboada et al., 2000] transition zone at $\sim 5^{\circ} \mathrm{N}$.

[46] The age of the NAB northward drifting has been constrained considering mainly the age of the bounding tectonic features. In Colombia the NAB drifting is accommodated along the Guaicaramo-Algeciras fault [i.e., Velandia et al., 2005; Dimate et al., 2003]. Quaternary tectonic features are documented along this fault but no timing for the beginning of the tectonic deformation is proposed. In Ecuador, Lavenu et al. [1995] and Winkler et al. [2005] suggest that the Inter-Andean basins developed in a transpressive tectonic regime related to NAB northward drifting during the past 5-6 Myr. Even so, Lavenu et al. [1995] argue that although the formation of the Inter-Andean valley probably began in the late Miocene, the structural analysis demonstrates that it was subjected to major E-W shortening between 1.85 and 1.21 Ma. Furthermore, in the zone where the NAB eastern limit swings to the GG area a major pullapart basin formed along a transtensional-releasing bend. This pull-apart basin began to form $~ 2.5$ Myr ago [Winter and Lavenu, 1989]. Similarly, Winkler et al. [2005] defined a major phase of compression younger that 2.9 Ma along the northern Inter-Andean valley. These results support our interpretation that a major reorganization of the NAB limits took place at the Plio-Quaternary boundary. Furthermore, roughly dated Quaternary changes in the tectonic regime of the central part of the Inter-Andean valley has been related to major changes in the slip of the faults bounding the NAB [Tibaldi and Ferrari, 1992; Villagomez et al., 2002].

[47] East of the GG area, the Andean foothills of the Western Cordillera underline a $\sim 100 \mathrm{~km}$ displaced zone (southernmost prolongation of the Calacalí-Pallatanga fault) that has been linked with the dextral slip at the origin of the GG area [Steinmann et al., 1999; Hungerbühler et al., 2002]. To consider that the opening of the GG is of Quaternary age combined with the $\sim 1 \mathrm{~cm} / \mathrm{yr}$ rate of NAB northward drifting only $\sim 20 \mathrm{~km}$ of northward drifting of the NAB may account for Quaternary times. Mainly on the basis of paleogeographic reconstructions and facies correlations Steinmann et al. [1999] and Hungerbühler et al. [2002] suggest a direct connection between the Manabí and Progreso coastal basins and the Inter-Andean basins, prior to the uplift of the Andes. They propose that opening of the GG area occurred $\sim 10$ Myr ago and that the opening of the GG area is related to the $\sim 100 \mathrm{~km}$ offset of the Andean foothills along the Calacalí-Pallatanga fault. This interpretation of data allows them to properly match the postulated $\sim 100 \mathrm{~km}$ offset and the NAB migration with a $10 \mathrm{Myr}$ ongoing dextral displacement. Following Steinmann et al. [1999] and Hungerbühler et al. [2002], the GG area 
subsidence has to start during the late Miocene. Our data do not allow us to speculate about the connection between the forearc and Inter-Andean basins. However, our data of the GG area document a major discrepancy with this model: the main subsidence of the GG depocenters began during the early Pleistocene following a stable Pliocene period during which no significant tectonic deformation occurred. We thus consider that the $\sim 100 \mathrm{~km}$ of right-lateral slip along the so-called Calacalí-Pallatanga fault zone cumulated northward drifting from tectonic events as old as the Paleocene [Dunkley and Gaibor, 1997; Pecora et al., 1999; Hughes and Pilatasig, 2002; Kerr et al., 2002]. Furthermore, the $\sim 20 \mathrm{~km}$ NAB northward drifting that occurred during the Quaternary time is consistent with the total net lengthening calculated across a N-S section from the Santa Elena rise (Ecuador) to the Amotape massif (Peru) [Witt et al., 2006]. Whatever the old terrane accretion phases are, the modern construction of NAB limits (i.e., since early Pleistocene) started from reactivation of ancient suture zones as previously proposed along northern NAB boundaries [Audemard, 1997; Guillier et al., 2001; Dimate et al., 2003; Winkler et al., 2005]. However, our conclusions leave an open question regarding the origin of the Pliocene stable tectonic phase. An understanding of this point could be achieved considering the along trend morphology of the Carnegie ridge which show a major central saddle associated with a ridge necking at about $85-86^{\circ} \mathrm{W}$ longitude. Such a lowering and associated necking of the Carnegie ridge relief entering the subduction may be related with low coupling at the plate interface and consequently with lower rates of NAB drifting.

\subsection{Carnegie Ridge History}

[48] On the basis of onshore offshore wide-angle seismic data, a minimum age of $1.4 \mathrm{Ma}$ for the Carnegie ridge subduction was proposed [Graindorge et al., 2004]. Ages for the Carnegie ridge collision with the trench axis were proposed from onshore offshore geophysical studies. Several first-order constraints were obtained from intensive surveys of the Galapagos igneous province combining seismic reflection, gravity, magnetic, and heat flow records [i.e., Malfait and Dinkelman, 1972; Rea and Malfait, 1974; Hey, 1977; Lonsdale, 1978; Lonsdale and Klitgord, 1978; Pilger, 1984; Wilson and Hey, 1995; Meschede and Barckhausen, 2000; Sallarès and Charvis, 2003]. These works provide constraints to show that the Nazca plate has a complex plate tectonic history in relation with asymmetrical and complex tectonic history of the Cocos-Nazca spreading center. Aseismic ridges and their associated seamounts are not only the surficial manifestation of hot spot activity but also reflect regional tectonic events including spreading centers jumps and migration. As a consequence, no simple relation between distance and convergence rate can be established to date the arrival of the Carnegie ridge to the trench axis. Models have been proposed suggesting that ridge-trench collision occurred at the Pliocene-early Pleistocene boundary [Rea and Malfait, 1974; Hey, 1977; Lonsdale, 1978; Lonsdale and Klitgord, 1978; Wilson and Hey, 1995]. However, older ages for the ridge collision were proposed including the late Miocene [Pilger, 1984] and the early Miocene [Malfait and Dikleman, 1972].

\subsection{Slab Geometry}

[49] Daly [1989] explored the possible relationship between slab geometry and the evolution of the forearc area. During the late Miocene, the Carnegie ridge subduction may have triggered a regional tectonic inversion along the forearc. However, he noted that the Carnegie ridge subduction occurred too late to be the unique factor responsible for the inversion. Benitez [1995] proposed an extensive analysis of the forearc stratigraphy and deformation. He shows that the uplift of the forearc area, including the Manabí and Progresso basins originated from a tectonic inversion, which occurred during the Quaternary time. He thus favored a Quaternary age for the ridge subduction. Subsequently, Deniaud [2000] minimized the unconformity documented at the base of the Pleistocene [Benitez, 1995; this work]. On the basis of this assumption they proposed an older age for the Carnegie ridge subduction to begin. Recently, analyses of marine terrace uplift allowed Pedoja [2003] and Cantalamessa and Di Celma. [2004] to argue that ridge subduction began at the late Pliocene-early Pleistocene limit. Similarly, an important post-Pliocene change of the extensional tectonic regime that characterized the Borbón basin was associated with the subduction of the ridge by Aalto and Miller [1999]; they also proposed a Quaternary age for the ridge subduction.

[50] Other models such as Gutscher et al [1999] suggest that the Carnegie ridge subduction began $8 \mathrm{Myr}$ ago. Those models imply the subducted ridge segments to extend far to the east beneath the Andes. They argue from three major points including (1) a suggested feedback mechanism between uplift and subsidence related to the southward migration of the ridge along the forearc, (2) a seismic gap of intermediate seismicity (flat slab model), and (3) the existence of an adakite volcanism. More recent works dealing specifically with each of these three particular points [Guillier et al., 2001; Pedoja, 2003; Cantalamessa and Di Celma, 2004; Garrison and Davidson, 2003; Stern, 2004; Samaniego et al., 2005; Kay, 2005] have presented evidences against the flat slab model and the related $8 \mathrm{Ma}$ age for ridge subduction initiation. The adakite volcanism extensively recognized along the broad Ecuador volcanic arc was proposed to either originate from lithospheric tears separating the flat Carnegie ridge from the steeper adjacent segments or the slab flattening itself. It is postulated that higher degrees of slab melting can be obtained from higher geothermal gradient originating from ridge flattening [Samaniego et al., 2002]. In that manner, the adakitic signal, which occurred since $1.5 \mathrm{Ma}$ has been interpreted as ridge induced. Consequently, the ridge collision with the trench was proposed to occur at 5 Myr ago. Recently, Samaniego et al. [2005] related an increase in adakitic products at about $0.4 \mathrm{Ma}$ with the arrival of the Carnegie ridge to the trench axis. Also extensive evidence was presented from numerous studies documenting that adakites in the Andes can be explained by equilibration of mantle wedge derived arc magma with thickened garnet-bearing continental crust 
rather than by melting of subducted oceanic slabs [Garrison and Davidson, 2003; Stern, 2004; Kay, 2005, and references therein].

[51] Along-strike segmentation of the thermal and tectonic response along the Eastern Cordillera of the Ecuadorian Andes [Spikings et al., 2001] was also attributed to differing along-strike subducted slab age, strength and composition. North of $1^{\circ} 30 \mathrm{~S}$, the development of higher topography and elevated cooling rates at $\sim 15 \mathrm{Ma}$ (north highest rates up to $50^{\circ} \mathrm{C} / \mathrm{Myr}$ i.e., $\sim 1.4-1.5 \mathrm{~mm} / \mathrm{yr}$ uplift rate) and $\sim 9 \mathrm{Ma}$ (south highest rates up to $30^{\circ} \mathrm{C} / \mathrm{Myr}$ i.e., $\sim 0.8-1 \mathrm{~mm} / \mathrm{yr}$ uplift rate) are associated with the presence of the postulated subducted flat slab at depth. It is suggested that Carnegie ridge collided with the trench at $\sim 15 \mathrm{Ma}$ and that subsequent interplate coupling produced the high $9 \mathrm{Ma}$ exhumation rates. Beyond the uncertainty of the flat slab at depth, the along-strike segmentation of the Andean chain is questionable. In the southern Ecuadorian Andes (south of $\left.2^{\circ} 30^{\prime} \mathrm{S}\right)$, Steinmann et al. [1999], Hungerbühler et al. [2002] have defined a high cooling rate at $\sim 9 \mathrm{Ma}$ coeval with that documented north of $1^{\circ} 30^{\prime} \mathrm{S}$ [Spikings et al., 2001]. Interestingly, Hungerbühler et al. [2002] defined a $\sim 0.7 \mathrm{~mm} / \mathrm{yr}$ high uplift rate south of $2^{\circ} 30^{\prime} \mathrm{S}$ from $9 \mathrm{Ma}$ to Present. Instead of being located far to the south, this uplift phase is also related with the Carnegie ridge subduction. Furthermore, southward along the Huayhuash Cordillera in northern Peru $\left(\sim 10^{\circ} \mathrm{S}\right)$ the same $9-10 \mathrm{Ma}$ cooling period was documented from the same termochronometric approach [Garver et al., 2005]. Here no ridge exists, and the area is located far away from the Nazca Ridge collision zone [Hampel, 2002]. Similarly, along the Eastern Cordillera of Colombia a comparable cooling event (with series cooling from temperatures of about $100^{\circ}-150^{\circ} \mathrm{C}$ ) of late Miocene age was also inferred from fission track analyses [Gomez et al., 2003, 2005]. An extensive review of the uplift history of the central and northern Andes suggest that the 10-15 Ma uplift period was also important in the Bolivia and Chile cordilleras [Gregory-Wodzicki, 2000]. In addition, younger cooling steps have been identified in Ecuador between 3 and $5 \mathrm{Ma}$, as a regional event south of $2^{\circ} 45^{\prime} \mathrm{S}$ [Steinmann et al., 1999; Hungerbühler et al., 2002] and as a local imprint north of $2^{\circ} 45^{\prime} \mathrm{S}$ [Spikings and Crowhurst, 2004]. The Plio-Quaternary cooling event was also documented in the Eastern Cordillera of Colombia and in the Mérida Andes of Venezuela [Gregory-Wodzicki, 2000; Audemard, 2003; Gomez et al., 2003, 2005]. Widespread cooling events have been observed in the Andes for at least the past $25 \mathrm{Myr}$ and possibly represent an ongoing process. There appears to be no distinct cooling period linked with the Carnegie ridge subduction area or with its landward postulated prolongation at depth.

[52] As describes above, a late Miocene ( $~ 8-10 \mathrm{Ma})$ and a late Pliocene-Quaternary $(\sim 3-2 \mathrm{Ma})$ are the two main proposed ages for the collision of the Carnegie ridge with the trench axis. Along the Ecuadorian forearc, the GG area is the zone of greatest deformation occurring during Quaternary. Since the oblique convergence remains constant for at least the past $5 \mathrm{Myr}$ and because the evolution of the GG area is strictly controlled by the northward migration of the
NAB we assume that a major reorganization of the NAB northward drifting occurs at the Pliocene-early Pleistocene boundary. We assume that the subduction of the Carnegie ridge is at the origin of the increase of the interplate coupling involved in the acceleration of the NAB migration. At present times an elastic locking of $\sim 50 \%$ of the convergence movement is taking place along the subduction zone [White et al., 2003]. This locking matches the NAB displacement rate of $\sim 1 \mathrm{~cm} / \mathrm{yr}$ [Trenkamp et al., 2002; White et al., 2003]. Moreover, the Carnegie ridge is $\sim 10 \mathrm{~km}$ thicker than the surrounding oceanic crust [Gallier, 2005]. Following the Scholz and Small [1997] model, this excess of crust thickness would induce an increase interplate coupling of at least $\sim 200 \mathrm{MPa}$ (buoyancy not included). We consider that such an interplate coupling increase is high enough to modify the kinematics of a wide zone, especially if the NAB is considered as a rigid block [Guillier et al., 2001; Trenkamp et al., 2002; White et al., 2003]. Therefore we consider that the GG area has recorded the history of plate coupling in relation to the Carnegie ridge collision. In the GG area, the main tectonic deformation and related subsidence began by the beginning of early Pleistocene suggesting that the Carnegie ridge collision or the collision of an along-strike positive did not begin much earlier than at that time (i.e., $\sim 1.8-1.6 \mathrm{Ma}$ ). If subduction of the Carnegie ridge has been a constant process since late Miocene times [Pilger, 1984; Spikings et al., 2001] the subduction of a positive relief would explain the documented major reorganizations in the forearc deformation regime during the Plio-Quaternary limit [Deniaud et al., 1999; Aalto and Miller, 1999; Pedoja, 2003; Cantalamessa and Di Celma, 2004] including NAB northward drifting acceleration.

\section{Conclusions}

[53] The tectonic analysis of the GG area allows us to identify two major detachment systems: the Posorja (PDS) and the Jambelí (JDS) detachment systems. These two detachments exhibits opposite verging slip direction, to the south and to the north, respectively. The N-S trending Puná-Santa Clara fault system (PSCFS), developed as a transfer fault system between the PDS and the JDS. It accommodated the opposite motion of the two opposite verging detachment systems. It thus exhibits no prolongation to the north and to the south. The Esperanza and the Jambelí basins exhibit $3-4 \mathrm{~km}$ of sediment that accumulated during the past 1.6-1.8 Myr. The PSCFS bound the Esperanza and the Jambelí basins, evidencing that the evolution of these basins is strictly controlled by the two Posorja and Jambelí detachment systems. To the west, the N-S trending Domito fault system (DFS) acted as a transfer zone between the shelf area and the continental slope. The DFS bounds the PDS and the Esperanza basin to the west.

[54] The Pliocene series observed in the Esperanza and Jambelí basin areas show no significant variations in thickness throughout the GG area suggesting that no substantial deformation occurred from 5.2 to $1.6-1.8 \mathrm{Ma}$. By contrast, a pervasive Miocene-Pliocene extensional tectonics is observed west the DFS in conjunction with N-S trending 
normal faults dipping seaward. These faults are considered as related to subduction erosion working at depth as demonstrated elsewhere along convergent margins [Scholl et al., 1980; Aubouin et al., 1982, 1984; Bourgois et al., 1984, 1988; von Huene et al., 1989]. An E-W tensional stress regime prevailed along the continental margin since Miocene time. In early Pleistocene time the E-W trending PDS and JDS controlled the subsidence of the Esperanza and Jambelí basins. Therefore a N-S tensional stress regime characterized the GG shelf area during the past 1.6-1.8 Myr. As previously proposed, we consider that the N-S tensional stress regime of the GG area is the effect of the NAB northward drift. The DFS marks the limit between an area strongly controlled by margin processes (i.e., the upper continental slope) and another one (i.e., the shelf area) strongly controlled by the tectonic escape of the NAB. This reflects that part of the partitioning motion is accommodated along the DFS. The major period of deformation in the GG area occurred in early Pleistocene times. Taking into account the strong dependence of the subsidence in the GG area with respect to the northward drifting of the NAB, we assume that the Pliocene-early Pleistocene boundary is associated with a major change in the northward migration rate of the NAB. No major kinematic reorganization occurred along the Nazca-South America plate boundary since the Pliocene (5.2 Ma) that would explain the higher rate of the NAB northward drifting during early Pleistocene time. Therefore we postulate that the collision of the Carnegie ridge with the trench axis must play a major role in controlling the NAB northward drift. Because evidences exist for northward drift of the NAB prior to Miocene time, we assume that the increase of the interplate coupling at the Pliocene-early Pleistocene boundary originated from the Carnegie ridge itself. We postulate that the along-strike morphology of the ridge is possibly at the origin of interplate coupling variations.

[55] A major exposure of the GG area occurred during glacial sea level fall of isotopic substage 6e (between 180 and $140 \mathrm{ka}$ ). This exposure induced the accumulation of marine sediment to stop. Also this major paleogeographic change probably caused local strain changes able to have tectonic signatures. These are the so-called late Pleistocene compressional deformations confined to two small segments of the PSCFS and the central segment of the Tenguel fault. We consider that these local contractive tectonic features (inversion) have local causes. Indeed no cinematic reorganization at plate boundaries existed at that time. Therefore we assume that no major change in the general tectonic regime existed during the Quaternary evolution of the GG area. The GG area has been in an extensional stress regime since the early Pleistocene. At Present time, the tectonics of the studied area is dominantly extensional. In the GG area it is concentrated along the Esperanza graben and along the Tenguel fault. The DFS shows reactivation as a normal fault in recent times while the Posorja and Jambelí detachments are no longer active.

[56] Detrital material discharges from the two major Ecuadorian Andean-coastal drainage basins provide great sediment input to the GG area. During the isotopic substage 6 low stand, the exposure of the GG area allows the sediments to reach the trench axis instead of being trapped in the GG area. It has been shown elsewhere [i.e., von Huene and Scholl, 1991; Bourgois et al., 2000] that sediment supply to the trench axis is a major cause for the tectonic regime to switch from subduction-erosion to subduction-accretion. This reflects the potential importance of the GG area in controlling the tectonic regime along the southern Ecuadorian margin. Indeed the turbidite trench fill has recently accreted against the margin backstop off the GG area [Collot et al., 2002]. During the cold period of isotopic substage 6 , the detrital material bypassing the GG allows rapid increase in trench deposition. Instead a postulated asperity subduction, variation in the sediment supply to the trench axis could explain more convincingly the tectonic regime of the margin to switch from subduction erosion to subduction accretion.

[57] Acknowledgments. This study was supported by the Fundacyt (Ecuador), the French Embassy in Quito, the Institut de Recherche pour le Developpement (IRD, France), and the Centre National de la Recherche Scientifique (CNRS, France). We are grateful to Petroproduccion for providing the basic data for this work including drilling and seismic records. We thank Wilfred Winkler and Richard Spikings for their critical and constructive reviews. Their comments greatly improved the original manuscript.

\section{References}

Aalto, K. R., and W. Miller (1999), Sedimentology of the Pliocene Upper Onzole Formation, an innertrench slope succession in northwestern Ecuador, J. S. Am. Earth Sci., 12, 69-85.

Acosta, J., L. Lonergana, and M. P. Coward (2004), Oblique transpression in the western thrust front of the Colombian Eastern Cordillera, J. S. Am. Earth Sci., 17, 181-194.

Angelier, J., and B. Coletta (1983), Tension fractures and extensional tectonics, Nature, 301, 49-51.

Aubouin, J., et al. (1982), Leg 84 of the Deep Sea Drilling Project: Subduction without accretion: Middle America Trench off Guatemala, Nature, $297,458-460$

Aubouin, J., J. Bourgois, and J. Azéma (1984), A new type of active margin: The convergent-extensional margin, as exemplified by the Middle America Trench off Guatemala, Earth Planet. Sci. Lett., 67, $211-218$.
Audemard, F. (1997), Holocene and historical earth quakes on the Boconó fault system, southern Venezuelan Andes: Trench confirmation, J. Geodyn., 24, $155-167$.

Audemard, F. (2003), Geomorphic and geologic evidence of ongoing uplift and deformation in the Mérida Andes, Venezuela, Quat. Int., 101-102, 4365.

Benitez, S. (1995), Évolution géodynamique de la province côtière sud-équatorienne au Crétacé supérieur Tertiaire, Ph.D. thesis, 221 pp, Univ. Grenoble 1, Grenoble, France, 11 July.

Benitez, S., E. Jaillard. M. Ordoñez, and N. Jimenez (1993), Late Cretaceous to Eocene tectonic sedimentary evolution of southern coastal Ecuador: Geodynamic implications, paper presented at 2nd International Symposium of Andean Geodynamics, Inst. de Rech. pour le Dev., Oxford, U.K., $21-23$ Sept.
Berggreen, W. A., D. V. Kent, and J. J. Flynn (1985), Paleogene geochronology and chronostratigraphy, the chronology of the geological record, Mem. Geol. Soc. Am., 10, 141-195.

Boinet, T., J. Bourgois, H. Mendoza, and R. Vargas (1985), Le poinçon de Pamplona (Colombie): Un jalon de la frontière méridionale de la plaque Caraïbe, Bull. Soc. Géol. Fr., 8(1), 403413.

Bourdon, E., J. P. Eissen, M. A. Gutscher, M. Monzier, M. L. Hall, and J. Cotten (2003), Magmatic response to early aseismic ridge subduction: The Ecuadorian margin case (South America), Earth Planet. Sci. Lett., 205, 123-138.

Bourgois, J., B. Calle, J. Tournon, and J. F. Toussaint (1982), The Andean ophiolitic megastructures on the Buga-Buenaventura transverse (Western Cordillera-Valle, Colombia), Tectonophysics, 82, $207-229$. 
Bourgois, J., J. Azéma, P. O. Baumgartner, J. Tournon, A. Desmet, and J. Aubouin (1984), The geologic history of the Caribbean-Cocos plate boundary with special reference to the Nicoya ophiolite complex (Costa Rica) and D.S.D.P. (legs 67 and 84 off Guatemala): A synthesis, Tectonophysics, 108, 1-32.

Bourgois, J., J. F. Toussaint, H. Gonzalez, J. Azéma, B. Calle, A. Desmet, L. A. Murcia, A. P. Acevedo, E. Parra, and J. Tournon (1987), Geological history of the Cretaceous ophiolitic complexes of northwestern South America (Western and Central cordilleras of the Colombia Andes), Tectonophysics, 143, 307327.

Bourgois, J., et al. (1988), Seabeam and seismic reflexion imaging of the tectonic regime of the Andean continental margin off Peru $\left(4^{\circ} \mathrm{S}\right.$ to $\left.10^{\circ} \mathrm{S}\right)$, Earth Planet. Sci. Lett., 87, 111-126.

Bourgois, J., A. Eguez, J. Butterlin, and P. De Wever (1990), Evolution géodynamique de la Cordillère Occidentale des Andes d'Equateur: La découverte de la Formation éocène d'Apagua, C. R. Acad. Sci., 311(2), $173-180$.

Bourgois, J., C. Guivel, Y. Lagabrielle, T. Calmus, J. Boulègue, and V. Daux (2000), Glacial-interglacial trench supply variation, spreading-ridge subduction, and feedback controls on the Andean margin development at the Chile triple junction area $\left(45-48^{\circ} \mathrm{S}\right)$, J. Geophys. Res., 105, 8355-8386.

Buck, W. R. (1988), Flexural rotation of normal faults, Tectonics, 7, 959-973.

Calahorrano, A. (2005), Structure de la marge du Golfe de Guayaquil (Equateur) et propriété physique du chenal de subduction, à partir de données de sismique marine réflexion et réfraction, Ph.D. thesis, 227 pp, Univ. Paris VI, Paris.

Campbell, C. J. (1974), Ecuadorian Andes, in Mesozoic Cenozoic Orogenic Belts: Data for Orogenic Studies, edited by A. M. Spencer, Geol. Soc. Spec. Publ., 4, 725-732.

Cande, S. C., and D. V. Kent (1995), Revised calibration of the geomagnetic polarity time scale for the Late Cretaceous and Cenozoic, J. Geophys. Res., 100, 6093-6095.

Cantalamessa, G., and C. Di Celma (2004), Origin and chronology of Pleistocene marine terraces of Isla de la Plata and of flat, gently dipping surfaces of the southern coast of Cabo San Lorenzo (Manabí, Ecuador), J. S. Am. Earth Sci., 16, 633-648.

Cloos, M. (1992), Thrust-type subduction-zone earthquakes and seamount asperities: A physical model for seismic rupture, Geology, 20, 601-604.

Collot, J. Y., P. Charvis, M. Gutscher, and E. Operto (2002), Exploring the Ecuador-Colombia active margin and inter-plate seismogenic zone, Eos Trans. $A G U, 83(17), 185,189-190$

Corredor, F. (2003), Seismic strain rates and distributed continental deformation in the northern Andes and three-dimensional seismotectonics of the northwestern South America, Tectonophysics, 372, $147-166$.

Cortés, M., J. Angelier, and B. Colletta (2005), Paleostress evolution of the northern Andes (Eastern Cordillera of Colombia): Implications on plate kinematics of the south Caribbean region, Tectonics, 24, TC1008, doi:10.1029/ 2003 TC001551.

Daly, M. C. (1989), Correlations between NazcaFarallon plate kynematics and forearc basin evolution in Ecuador, Tectonics, 8, 769-790.

Deniaud, Y. (2000), Enregistrements sédimentaire et structurale de l'évolution géodynamique des Andes équatoriennes au cours du Néogène: Etude des bassins d'avant-arc et bilans de masse, Ph.D. thesis, 157 pp, Univ. Grenoble 1, Grenoble, France.

Deniaud, Y., P. Baby, C. Basile, M. Ordoñez, G. Montentegro, and G. Mascle (1999), Ouverture et évolution tectono-sedimentaire du Golfe de Guayaquil: Basin d'avant arc néogène et quaternaire du Sud des Andes équatoriennes, C. R. Acad. Sci., 328(3), $181-187$

Dhont, D., G. Backé, and Y. Hervoüet (2005), PlioQuaternary extension in the Venezuelan Andes:
Mapping from SAR JERS imagery, Tectonophysics, 399, 293-312.

Dimate, C., L. Rivera, A. Taboada, B. Delouis, A. Osorio, E. Jimenez, A. Fuenzalida, A. Cisternas, and I. Gomez (2003), The 19 January 1995 Tauramena (Colombia) earthquake: Geometry and stress regime, Tectonophysics, 363, 159-180.

Dumont, J., E. Santana, and W. Vilema (2005) Morphologic evidence of active motion of the Zambapala Fault, Gulf of Guayaquil (Ecuador), Geomorphology, 65, 223-239.

Dunkley, P., and A. Gaibor (1997), Geology of the Cordillera Occidental of Ecuador between $2-3^{\circ} \mathrm{S}$, Proyecto de Desarrollo Miner. y Control Ambiental, Programa de Inf. Cartog. y Geol., CODIGEM-BGS, Quito, Equador.

Ego, F., M. Sébrier, A. Lavenu, H. Yepes, and A. Eguez (1996), Quaternary state of stress in the northern Andes and the restraining bend model for the Ecuadorian Andes, Tectonophysics, 259, 101-116.

Eguez, A., A. Alvarado, H. Yepes, M. Machette, C. Costa, and R. Dart (2003), Database and map of Quaternary faults and folds of Ecuador and its offshore regions, U.S. Geol. Surv. Open File Rep., 03289

Feininger, T., and C. R. Bristow (1980), Cretaceous and Palaeogene geologic history of coastal Ecuador, Geol. Rundsch., 69, 849-874.

Freymueller, J. T., J. Kellog, and V. Vega (1993), Plate motions in the north Andean region, J. Geophys. Res., 98, 21,853-21,863.

Gallier, A. (2005), Structure de la marge d'Equateur-Colombie par modélisation des données de sismique grand angle marines: Influence sur le fonctionnement de la subduction et la sismicité Ph.D. thesis, Univ. Nice-Sophia Antipolis, Nice, France.

Garrison, J., and J. Davidson (2003), Dubious case of slab melting in the northern volcanic zone of the Andes, Geology, 31, 565-568.

Garver, J. I., P. W. Reiners, L. Walker, J. Ramage, and S. E. Perry (2005), Implications for timing of Andean uplift from thermal resetting of radiationdamaged Zircon in the Cordillera Huayhuash, northern Peru, J. Geol., 113, 117-138.

Gomez, E., T. E. Jordan, R. W. Allmendinger, K. Hegarty, S. Kelleey, and M. Heizler (2003), Controls on architecture of the Late Cretaceous to Cenozoic southern Middle Magdalena Valley Basin, Colombia, Geol. Soc. Am. Bull., 115, 131-147.

Gomez, E., T. E. Jordan, R. W. Allmendinger, K. Hegarty, and S. Kelleey (2005), Syntectonic Cenozoic sedimentation in the northern middle Magdalena Valley Basin of Colombia and implications for exhumation of the northern Andes, Geol. Soc. Am. Bull., 117, 547 569.

Graindorge, D., A. Calahorrano, P. Charvis, J. Y. Collot, and N. Bethoux (2004), Deep structures of the Ecuador convergent margin and the Carnegie Ridge, possible consequence on great earthquakes recurrence interval, Geophys. Res. Lett., 31, L04603, doi:10.1029/2003GL018803.

Gregory-Wodzicki, K. (2000), Uplift history of the central and northern Andes: A review, Geol. Soc. Am Bull., 112, 1091-1105.

Guillier, B., J. L. Chatelain, E. Jaillard, H. Yepes, G. Poupinet, and J. F. Fels (2001), Seismologica evidence on the geometry of the orogenic system in central-northern Ecuador (South America), Geophys. Res. Lett., 28(19), 3749-3752.

Gutscher, M. A., J. Malavieille, S. Lallemand, and J. Y Collot (1999), Tectonic segmentation of the north Andean margin: Impact of the Carnegie ridge collision, Earth Planet. Sci. Lett., 168, 255-270.

Hampel, A. (2002), The migration history of the Nazca Ridge along the Peruvian active margin: A re-evaluation, Earth Planet. Sci. Lett., 203, $665-679$.

Haq, B. U., J. Hardenbold, and P. R. Vail (1988), Mesozoic and Cenozoic chronostratigraphy and cycles of sea-level change, Spec. Publ. Soc. Econ. Paleontol. Mineral., 42, 71-108.
Hey, R. (1977), Tectonic evolution of the Cocos-Nazca spreading center, Geol. Soc. Am. Bull., 88, 14041420

Hughes, R., and L. Pilatasig (2002), Cretaceous and Tertiary terrane accretion in the Cordillera Occidental of the Andes of Ecuador, Tectonophysics, 345 , $29-48$

Hungerbühler, D., M. Steinmann, W. Winkler, D. Seward, A. Eguez, D. E. Peterson, U. Helg, and C. Hammer (2002), Neogene stratigraphy and Andean geodynamics of southern Ecuador, Earth. Sci. Rev., 57, $75-124$.

Jaillard, E., S. Benítez, and G. Mascle (1997), Les déformations paléogènes de la zone d'avant-arc sudéquatorienne en relation avec l'évolution géodynamique, Bull. Soc. Geol. Fr., 168(4), 403-412.

Kay, S. M. (2005), Andean adakites from slab melting, forearc subduction erosion and crustal thickening, paper presented at 12th Congreso Latinoamericano de Geologia, Col. de Ing. Géol. De Pichincha, Quito, Ecuador.

Kellogg, J. N., and V. Vega (1995), Tectonic development of Panama, Costa Rica and the Colombian Andes: Constraints from Global Positioning System (GPS) geodetic studies and gravity, in Geologic and Tectonic Development of the Caribbean Plate Boundary in Southern Central America, edited by P. Mann, Spec. Pap. Geol. Soc. Am., 295, 75-90.

Kerr, A., J. Aspden, J. Tarney, and L. Pilatasig (2002), The nature and provenance of accreted oceanic terranes in western Ecuador: Geochemical and tectonic constraints, J. Geol. Soc. London, 159 $577-594$

Lambeck, K., Y. Yokoyama, and T. Purcell (2002), Into and out of the Last Glacial Maximum: Sea leve change during oxygen isotope stage 3 and 2, Quat. Sci. Rev., 21, 343-360.

Lapierre, H., et al. (2000), Multiple plume events in the genesis of the peri-Caribbean Cretaceous oceanic plateau province, J. Geophys. Res., 105, $8403-$ 8421

Lavenu, A., T. Winter, and F. Dávila (1995), A Pliocene-Quaternary compressional basin in the Interandean depression, central Ecuador, Geophys. $J$ Int., 121, 279-300.

Lonsdale, P. (1978), The Ecuadorian subduction system, AAPG. Bull., 62, 2454-2477.

Lonsdale, P., and K. Klitgord (1978), Structure and tectonic history of the eastern Panama Basin, Geol. Soc. Am. Bull., 89, 981-999.

Malfait, B. T., and M. G. Dinkelman (1972), CircumCaribbean tectonic and igneous activity and the evolution of the Caribbean plate, Geol. Soc. Am. Bull., 83, 251-272.

Mamberti, M., H. Lapierre, D. Bosch, E. Jaillard, R. Ethien, J. Hernandez, and M. Polvé (2003), Accreted fragments of the Late Cretaceous Caribbean-Colombian Plateau in Ecuador, Lithos, 66, $173-199$.

Meschede, M., and U. Barckhausen (2000), Plate tectonic evolution of the Cocos-Nazca spreading center, Proc. Ocean Drill. Program, Sci. Results, 170, $1-10$.

Pardo-Casas, F., and P. Molnar (1987), Relative motion of the Nazca (Farallon) and South America plate since late Cretaceous times, $\mathrm{Tec}$ tonics, 6, 233-248.

Pecora, L., E. Jaillard, and H. Lapierre (1999), Accrétion paléogene et décrochement dextre d'un terrain océanique dans le Nord du Perou, C. R. Acad. Sci., $329(6), 389-396$.

Pedoja, K. (2003), Les terrasses marines de la marge Nord Andine (Equateur et Nord Pérou): Relations avec le contexte géodynamique, Ph.D. thesis, 413 pp, Univ. Paris VI, Paris.

Pennington, W. D. (1981), Subduction of the eastern Panama Basin and seismotectonics of northwestern South America, J. Geophys. Res., 86, 10,75310,770 .

Pilger, R. H. (1984), Cenozoic plate kinematics, subduction and magmatism: South American Andes, J. Geol. Soc. London, 141, 793-802. 
Porter, S. C. (1989), Some geological implications of average Quaternary glacial conditions, Quat. Res., $32,245-261$.

Rea, D. K., and B. T. Malfait (1974), Geologic evolution of the northern Nazca Plate, Geology, 2, $317-$ 320

Reynaud, C., E. Jaillard, H. Lapierre, G. Mascle, and V. Dupuis (1999), Oceanic plateau and island arcs of southwestern Ecuador: Their place in the geodynamic evolution of the northwestern America Tectonophysics, 307, 235-254.

Sallarès, V., and P. Charvis (2003), Crustal thickness constraints on the geodynamic evolution of the $\mathrm{Ga}$ lapagos Volcanic Province, Earth Planet. Sci. Lett. 214, 545-559.

Samaniego, P., H. Martin, C. Robin, and M. Monzier (2002), Transition from calc-alkalic to adakitic magmatism at Cayambe volcano, Ecuador: Insight into slab melts and mantle wedge interactions, Geology, 30, 967-970

Samaniego, P., H. Martin, M. Monzier, C. Robin, M. Fornari, J. P. Eissen, and J. Cotten (2005), Temporal evolution of magmatism in the northern volcanic zone of the Andes: The geology and petrology of Cayambe Volcanic Complex (Ecuador), J. Petrol., 46(11), 2225-2252, doi:10.1093/petrology/egi053.

Scholl, D., R. von Huene, T. Vallier, and D. Howell (1980), Sedimentary masses and concepts about tectonic processes at underthrust ocean margins, Geology, 8, 564-568.

Scholz, C., and C. Small (1997), The effect of seamoun subduction on seismic coupling, Geology, 25, 487490

Shackleton, N. J. (1997), The deep sea sediment record at the Pliocene-Pleistocene boundary, Quat. Int., 40 $33-35$.

Shepherd, G. L., and R. Moberly (1981), Coastal structure of the continental margin northwest Peru and southwest Ecuador, in Nazca Plate: Crustal Formation and Andean Convergence, edited by L. D. Kulm et al., Mem. Geol. Soc. Am., 154, 351-391.

Soulas, J. P., A. Eguez, H. Yepes, and V. Perez (1991) Tectónica activa y riesgo sismico en los Andes ecuatorianos y el extremo sur de Colombia, Bol. Geol. Ecuat., 2(1), 3-11.

Spencer, J. E. (1984), Role of tectonic denudation in warping and uplift of low angle normal faults, Geology, 12, 95-98.

Spikings, R. A., and P. V. Crowhurst (2004), (U-Th)/He termochronometric constraints on the Late MiocenePliocene tectonic development of the northern Cor- dillera Real and the Interandean depression, Ecuador, J. South Am. Earth Sci., 17, 239-251.

Spikings, R. A., A. Winkler, D. Seward, and R. Handler (2001), Along-strike variations in the thermal and tectonic response of the continental Ecuadorian Andes to the collision with heterogeneous oceanic crust, Earth Planet. Sci. Lett., 186, 57-73.

Steinmann, M., D. Hungerbühler, D. Seward, and W. Winkler (1999), Neogene tectonic evolution and exhumation of the southern Ecuadorian Andes: A combined stratigraphy and fission track approach, Tectonophysics, 307, 255-276.

Stern, C. R. (2004), Active Andean volcanism: Its geologic and tectonic setting, Rev. Geol. Chile, 31 $161-206$.

Taboada, A., L. Rivera, A. Fuenzalida, A. Cisternas, H. Philip, H. Bjwaard, J. Olaya, and C. Rivera (2000), Geodynamics of the northern Andes: Subduction and intracontinental deformation (Colombia), Tectonics, 19, 787-873.

Tibaldi, A., and L. Ferrari (1992), Latest PleistoceneHolocene tectonics on the Ecuadorian Andes, Tectonophysics, 205, 109-125.

Trenkamp, R., J. N. Kellogg, T. Freymuller, and P. H Mora (2002), Wide plate margin deformation, southern Central America and northwestern South America, CASA GPS observations, J. South Am. Earth Sci., 15, 157-171.

Tzedakis, P. C., et al. (1997), Comparison of terrestria and marine records of changing climate of the last 500,000 years, Earth Planet. Sci. Lett., 150, 171 176.

Velandia, F., J. Acosta, R. Terraza, and H. Villegas (2005), The current tectonic motion of the northern Andes along the Algeciras Fault System in SW Colombia, Tectonophysics, 399, 313-329.

Villagomez, D., A. Eguez, W. Winkler, and R. Spikings (2002), Plio-Quaternary sedimentary and tectonic evolution of the central Inter-Andean Valley in Ecuador, paper presented at 4th Internationa Symposium on Andean Geodynamics (ISAG), Inst. de Rech. pour le Dév., Toulouse, France, $16-18$ Sept.

von Huene, R., and D. Scholl (1991), Observations at convergent margins concerning sediment subduction, subduction erosion, and the growth of continental crust, Rev. Geophys., 29(3), 279-316.

von Huene, R., E. Suess, and the Leg 112 Shipboard Scientists (1988), Ocean Drilling Program Leg 112 Peru continental margin: Part 1, Tectonic history, Geology, 16, 934-938. von Huene, R., J. Bourgois, J. Miller, and G. Pautot (1989), A large tsunamogenic landslide and debris along the Peru Trench, J. Geophys. Res., 94, 1703 1714

Wernicke, B. (1981), Low-angle faults in the Basin and Range province: Nape tectonics in an extending orogen, Nature, 291, 645-648.

White, S., R. Trenkamp, and J. Kellog (2003), Recent crustal deformation and the earthquake cycle along the Ecuador-Colombia subduction zone, Earth Planet. Sci. Lett., 216, 231-242.

Wilson, D. S., and R. Hey (1995), History of rift propagation and magnetization intensity for the CocosNazca spreading center, J. Geophys. Res., 100, $10,041-10,056$.

Winkler, W., D. Villagomez, R. Spikings, P. Abegglen, St. Tobler, and A. Eguez (2005), The Chota basin and its significance for the inception and tectonic setting of the inter-Andean depression in Ecuador, $J$ South Am. Earth Sci. 19, 5-19.

Winograd, I. J., J. M. Landwehr, K. R. Ludwig, T. B Tyler, and A. C. Riggs (1997), Duration and structure of the past four interglaciations, Quat. Res., 48, $141-154$

Winter, T., and A. Lavenu (1989), Morphological and microtectonic evidence for a major active rightlateral strike-slip fault across central Ecuador (South America), Ann. Tect., 3(2), 123-139.

Winter, T., J. Avouac, and A. Lavenu (1993), Late Quaternary kinematics of the Pallatanga strike slip fault (central Ecuador) from topographic measurements of displaced morphological features, Geophys. J. Int., 115, 905-920.

Witt, C., J. Bourgois, and F. Michaud (2006), Quaternary tectonic history of the Gulf of GuayaquilTumbes basin as the signature of the North Andean block tectonic escape, paper presented at the Backbone of the Americas, Geol. Soc. of Am., Mendoza, Argentina, 3-7 April.

J. Bourgois, F. Michaud, M. Sosson, and C. Witt, Geosciences Azur, La Darse BP. 48, F-06230 Villefranche-sur-Mer, France. (bourgois@ecua.net.ec micho@obs-vlfr.fr; sosson@obs-vlfr.fr; witt@obsvlfr.fr)

N. Jiménez and M. Ordoñez, Labogeo Petroproduccion, Via a Salinas, km 6 1/2, Guayaquil, Ecuador (cigg@telconet.net; marthaleonor5@hotmail.com) 